Danielle Palumbo

B.I.D. (High Honours), Sheridan College, 2014

\author{
A Major Research Paper \\ presented to Ryerson University \\ in partial fulfillment of the requirements for the degree of \\ Master of Planning \\ in \\ Urban Development
}

Toronto, Ontario, Canada, 2016

(C) Danielle Palumbo 2016 


\section{Author's Declaration for Electronic Submission of a MRP}

I hereby declare that I am the sole author of this MRP. This is a true copy of the MRP, including any required final revisions.

I authorize Ryerson University to lend this MRP to other institutions or individuals for the purpose of scholarly research.

I further authorize Ryerson University to reproduce this MRP by photocopying or by other means, in total or in part, at the request of other institutions or individuals for the purpose of scholarly research.

I understand that my MRP may be made electronically available to the public. 


\title{
NEIGHBOURHOOD RESILIENCE AND COMMUNITY HUBS IN ONTARIO
}

\author{
(C) Danielle Palumbo, 2016 \\ Master of Planning \\ in \\ Urban Development \\ Ryerson University
}

\begin{abstract}
This paper explores neighbourhood resilience in Ontario, and introduces recommendations for neighbourhoods interested in enhancing their resilience. Neighbourhoods are dynamic, complex, and experience variations of social, environmental and economic challenges. Resilience standards provide a lens that addresses the interconnected nature of these challenges. For the purpose of this paper, resilience focuses on a neighbourhood's ability to proactively respond and adapt to changes, emphasizing local capacity building, and meeting the neighbourhood's essential needs. The overall goal of neighbourhood resilience is to enhance well-being while experiencing stress, as well as after. Through a review of resiliencefocused literature, projects and approaches, it is clear that neighbourhoods are continuously changing, and require a holistic, comprehensive approach that fosters civic engagement and community connections. Ontario's Community Hub Strategic Framework and Action Plan, 2015 provides a foundation to support the flexible nature of community hubs in addressing neighbourhood resilience and meeting specific needs on a local-scale.
\end{abstract}

Keywords: "neighbourhood resilience" "community hubs" "strategic framework" "action plan" "proactive solutions" "civic engagement" "planning recommendations" 


\section{Acknowledgements}

Firstly, I want to thank all of my family and close friends, both near and far, for supporting me on this journey, they know who they are. I am grateful for all of their encouragement, patience, tea, dancing, and study breaks as I took them along for the ride. I especially want to thank my grandfather Peter Frankland for sharing his comprehensive knowledge and stories with me from a young age, and always encouraging me to dream big, work hard and believe in myself. Granddad, you are truly an inspiration. Thank you to all of my wonderful support systems for always believing in me, it truly did make a difference. I would also like to acknowledge my dear friend Jennie Fevreau for not only being there literally anytime I need her, but also for lending me her laptop when mine crashed a day before the first draft of this paper was due.

For this MRP, I especially want to thank my supervisor Dr. Zhixi C. Zhuang, and my second reader Randy Hodge for their incredible encouragement, support and insight. A special mention to Dr. Pamela Robinson for her contagious enthusiasm, and an extra special thank you to Julia Macan - you truly are a wonder woman, and words cannot express how appreciative I am for your dedication to this program and its students. I would also like to thank all of the School of Urban and Regional Planning Faculty members for creating such an extraordinary environment to learn and grow in. The lessons and opportunities that you have shared resonate deep inside me, and will never be forgotten.

Perhaps the most emotional acknowledgement is extended to my outstanding classmates. I have never felt as supported and energized by a group of people as I have with them, even through all of the hard work. I have learned more from this dynamic group of friends than I could have ever asked for, and I have developed friendships that will last a lifetime. I cherish all of our memories, through thick and thin, and look forward to the adventures ahead of us in a world outside of academia (!) I wish you all the best \#tojoe.

\section{Dedication}

It is with great pleasure and gratitude that I dedicate this paper to my parents, Mama Bev and Papa John. Words cannot express how wonderful my parents are, or the extent to which they have influenced my life in the most positive and uplifting ways. From a young age they encouraged my creativity and my passionate spirit, and patiently entertained my detailoriented, relentless antics. Surely there are times that they thought I was crazy, but regardless of the circumstances or degree of my activities, they supported me and did it with a smile (and containers of prepared healthy food). Even during the hardest times, I never doubted my abilities or felt discouraged for long because my parents wholeheartedly believed in me, gave me space to experience life in my own way, and encouraged me to meet my full potential. They remind me of what is truly important, and that I am capable of doing anything I set my mind to- a gift that I will always treasure. Thank you. This is for you.

“Okkkkkayyyy gooooooodnighttttttttt"- (Leeanna Mclean \& Christopher Palumbo, 2014)- two beautiful souls that always know just what to do and just what to say- I love you both dearly! 


\section{Table of Contents}

Abstract........................................................................

List of Tables............................................................ vi

List of Figures............................................................... vii

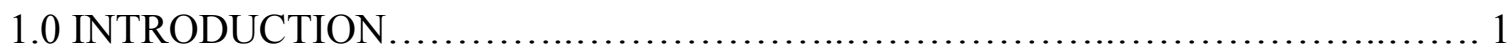

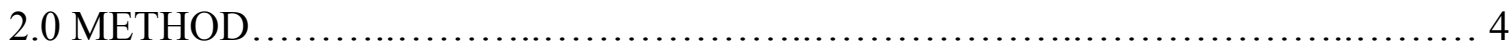

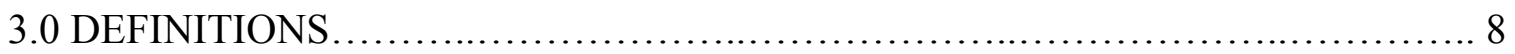

3.1 Neighbourhood and Community.......................................... 9

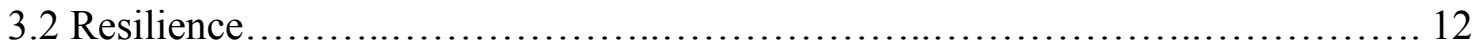

3.3 Community Hubs..................................................... 15

4.0 NEIGHBOURHOOD RESILIENCE .....................................20

4.1 Understanding Resilience at a Neighbourhood Scale.......................... 20

5.0 CASE STUDIES ANALYSIS AND MAIN FINDINGS ....................... 24

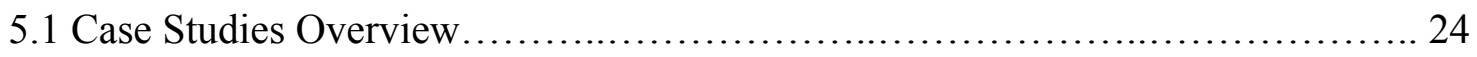

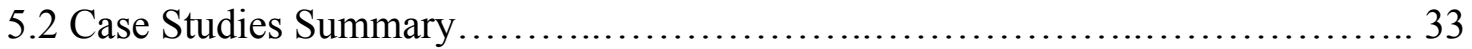

6.0 EXPLORING ONTARIO'S COMMUNITY HUBS STRATEGIC

FRAMEWORK AND ACTION PLAN'S CAPACITY TO ADDRESS

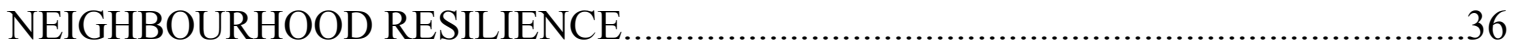

7.0 RECOMMENDATIONS- A NEIGHBOURHOOD RESILIENCE

FRAMEWORK \& “RESILIENCE TOOLKIT”................................43

8.0 CONCLUSIONS AND FINAL RECOMMENDATIONS.......................49

Reference List............................................................. 52 


\section{List of Tables}

Table 1- Case Studies Analysis and Main Findings

Table 2- Impact Analysis for a Neighbourhood in London, Ontario (energy system in the face of a heat wave risk)

Source: Uda, 2016, p.29

Table 3- Essential Needs Analysis for a Neighbourhood in London, Ontario (energy system in the face of a heat wave risk)

Source: Uda, 2016, p.29

Table 4- Issues That Present Opportunities for Ontario's Community Hubs Strategic Framework and Action Plan, 2015 to Address Resilience at a Neighbourhood-scale Table 5 - Suggested Framework and "Resilience Toolkit" 


\section{List of Figures}

Figure 1- What is a "Community Hub"?

Source: Queen's Printer for Ontario, 2015, p.7 


\subsection{INTRODUCTION}

Resilience has gained sizable interest in regards to the built environment in the past decade. Quirk (2013) shares the former American Institute of Architects president's declaration that “... resilience is the new Green..." and that it is important for cities, neighbourhoods and organizations to become more resilient to social, economic and physical challenges (p.1). Although a smaller-scale, "sustainable" rating system has been established, such as LEED for Neighbourhood Development, resilience at a neighbourhood-scale is a newer concept. Resilience is now a goal, much like sustainability, emerging from increased awareness of rapid change and its negative effects on built and social environments. This rapid change has great effects on cities and their neighbourhoods and associated communities, including, but not limited to, the increasing number of unexpected climate shocks and stresses (Uda, 2016), and the effects of infrastructure in need of major repair, gentrification and the loss of local businesses, an aging population, and rapid population growth. Along with these issues, there is also an increasingly high demand for affordable housing options, household debt is growing, and there is a clear and growing demand for local food security. These threats and stresses, as the result of rapid change, put pressure on all levels of government and nongovernment organizations, and it is apparent that local services and resources are feeling the effects as well (Fraser Basin Council et al., 2015).

A limited number of publications exist with a focus on resilience at the local-scale in Ontario, especially in regards to the social shocks and stresses that neighbourhoods face. However, projects with this lens are in place and emerging across Canada, especially in the western provinces such as Alberta and British Columbia, which are explored through case studies to support this research. As found through a literature review, another limitation exists in regards to establishing fixed definitions of "resilience" and "neighbourhood". Resilience is a complex and multidimensional planning issue that presents physical, social, and economic challenges in continuously changing environments, and neighbourhoods are unique, complex systems that embody both physical and social constructs that are constantly changing.

In addition to resilience research and development, it has also become a social, ecological and economic investment and responsibility for Ontario planners to understand how to develop community hubs to their full potential. Community hubs are a fairly new concept, at least in 
Ontario and at the regulatory and planning levels, but have been brought to the foreground recently with the introduction of Ontario's Community Hub Strategic Framework and Action Plan, 2015 initiated by Ontario Premier Kathleen Wynne in 2015. This framework and action plan has highlighted the more formal processes involved in the creation of community hubs, including the collaboration of government agencies, service providers, stakeholders, and the community, as well as the barriers and opportunities involved that need to be addressed to promote growth. Overall, the main concept behind community hubs is the co-location of services in one space, which vary substantially, in order to serve local needs. The main commonality found in community hubs is that they are shared spaces tailored to the specific needs of their communities. They are spaces where services and programs co-exist to provide support at varying levels for all members of the community within neighbourhoods that have their own specific needs. Community hubs are a great tool that planners and community organizations can utilize to focus on and address their community's unique needs, since community hubs provide the flexibility and resources to do so.

However, community hubs do need to be strengthened in the three major areas of coordinated planning, integrated service delivery and community infrastructure. The strategic framework and action plan highlights the need for a provincial community planning table, as well as multiple local planning tables, to move away from inflexible, one-size fits all service provision, and the requirement for hubs' future assets to be better designed to address changing local demographics and needs (Queen's Printer for Ontario, 2015). Additionally, after review of Ontario's Community Hub Strategic Framework and Action Plan, 2015 it is clear that the community's needs are best understood and known by the local community. What this suggests is that there is a need for, and an interest in, integrated local planning initiatives and approaches, which is a theme found repeatedly in emerging resilience approaches as well. Thus, there is an opportunity here to apply a more holistic and comprehensive local resilience lens to existing systems like community hubs, since they already support a similar philosophy. Both resilience and community hubs frameworks highlight that adapting and responding to changes and evolving community needs are at the core of truly sustainable systems, which ensures the long-term viability of community hubs, 
local service provision within a neighbourhood and thus local resilience (Bay Localize, 2015, Fraser Basin Council et al., 2015 \& Queen's Printer for Ontario, 2015).

With a clear need to apply a resilience lens at the local-scale in Ontario, and with the recent release of the Province's community hubs framework, the major questions this paper explores are:

1) How can neighbourhoods address resilience at a local-scale?

2) Can Ontario's Community Hubs Strategic Framework and Action Plan, 2015 provide an opportunity to integrate a resilience standard within the existing community hub model, and if yes, how?

These questions will be elaborated on in the next chapter and throughout the paper, but overall, with these main questions at its core, this research aims to spark a dialogue about the need to address resilience at a neighbourhood-scale through a more holistic, all-encompassing and proactive approach that involves tailored strategies, strong leadership (especially at the local-level) and civic engagement in particular. This paper also introduces a provincial community hubs framework that provides a possible local foundation that can be strengthened and built upon to support neighbourhood resilience through the application of a resilience lens and an integrated "Resilience Toolkit". As members of CIP and the OPPI, planners have a responsibility to improve quality of life, educate and engage, and to provide innovative solutions for the community (Canadian Institute of Planners, 2016). Implementing resilience at the neighbourhood-scale supports this mandate, empowers local communities and neighbourhoods, provides an opportunity for all members of society to engage, learn, and share in a way that generates proactive, customized growth, and increases the capacity of neighbourhoods to adapt and thrive in the face of rapid change. 


\subsection{METHOD}

With a clear need to apply a resilience lens at the local-scale in Ontario, and with the recent release of Ontario's Community Hubs Strategic Framework and Action Plan, 2015, the following questions are explored in this paper through secondary research that relies on secondary information, including existing literature, case studies, policies, frameworks, models, tools and statistics:

1) How can neighbourhoods address resilience at the local level?

a. How is "neighbourhood" defined?

b. How is "resilience" defined?

c. What is "neighbourhood resilience"?

d. What strategies, frameworks and tools are being used, or can be used to address resilience at the neighbourhood-scale in Canada? In Ontario?

2) Can Ontario's Community Hubs Strategic Framework and Action Plan, 2015 provide an opportunity to integrate a resilience standard within the existing community hub framework, and if yes, how?

a. What is a "community hub"?

b. What does Ontario's Community Hubs Strategic Framework and Action Plan, 2015 involve?

c. What opportunities exist within Ontario's Community Hubs Strategic Framework and Action Plan, 2015 that can support neighbourhood resilience?

d. How might hubs support resilience at a conceptual level?

3) What are the next steps required in order to further understand and address neighbourhood resilience?

a. In regards to neighbourhood resilience in general?

b. In regards to the community hubs framework?

With these questions at its core, this paper first explores and defines the terms "neighbourhood", "resilience", and "community hub" through a review of existing literature, 
case studies, policy documents and frameworks in order to answer how a "neighbourhood" can address resilience at a smaller-scale, and what "neighbourhood resilience" embodies. Secondary research and information is used because it provides a larger foundation and network of grounded information within a short timeframe than first hand interviews and field research can, especially since the concept of neighbourhood resilience is fairly new in Ontario at the regulatory and planning levels. This means that a lot of the neighbourhood resilience concepts, approaches and projects are still a work in progress, adapting to the constant changes involved in their smaller scopes, and have a more comprehensive foundation and thus, require more of a holistic research approach.

Additionally, secondary information and data on resilience as a field of study is accessed in order to define neighbourhood resilience in the context of this paper. This is done through a literature review of resilience from a global and city-wide perspective, exposing that very little research has been done at the local-level in regards to resilience projects and implementation, and then existing literature, case studies and data is used next to define resilience at a neighbourhood-scale. A literature review of the most recent resilience research within Ontario at a neighbourhood-scale conducted by Uda (2016) is used to understand how to analyze and implement a resilience framework at this scale. It focuses on analyzing neighbourhood resilience through developing a framework that identifies essential needs, future risks and interdependencies within the neighbourhood context as defined in this paper. The limitations exposed in this recent research and framework is that it has a heavier focus on the physical aspects and needs of a neighbourhood than the equally important social aspects and needs. Recognizing this limitation, a more holistic, proactive approach, and a comprehensive neighbourhood and community "Resilience Toolkit" are analyzed, and recommendations are made based on their all-encompassing approach to addressing resilience.

\section{Documents:}

- Planning Act, 1990

- $\quad$ PPS, 2014

- Growth Plan for the GGH, 2006

- Official Plans across Ontario, 2012-2015 


\section{Case Studies:}

- 10 case studies are used to provide recommendations for addressing neighbourhood resilience, and developing an associated framework

- Charleston, Gulfport and Memphis

- Faith \& the Common Good Pilot Projects

- T'Souke First Nation, British Columbia

- Sangudo Opportunity Development Cooperative, Alberta

- Transition Streets, McKaskill Street, British Columbia

- Neighbourhood's Alive! Manitoba

- London, Ontario based on Uda (2016)'s Neighbourhood Resilience research

Secondary information in the form of case studies and existing frameworks and tools is used to inform this research through understanding and interpreting recent practices, approaches and projects, and generating a conversation about how neighbourhoods might develop resilience strategies based on what is currently or has recently been successful. In order to answer to what extent Ontario's Community Hubs Strategic Framework and Action Plan, 2015 can address neighbourhood resilience, the provincial community hubs framework is explored through identifying the existing framework's goals and priorities and identifying challenges as potential opportunities for addressing resilience at the neighbourhood-scale. Since the research confirms that the community hubs framework does have the potential to address resilience at the neighbourhood-scale, the aforementioned holistic, proactive approach, and comprehensive "Resilience Toolkit" are assessed and interpreted, providing recommendations for integrating a resilience lens within Ontario's Community Hubs Strategic Framework and Action Plan, 2015.

Community Hubs in Ontario: Strategic Framework and Action Plan

- Provides background context; purpose of the study and plan

- Provides goals and priorities, and identifies challenges (that can be seen as potential opportunities) 


\section{Building Neighbourhood Resilience Approach:}

- Produced by Fraser Basin Council et al., 2015

- Provides a holistic, proactive, and comprehensive approach, as well as recommended people-focused and place-based strategies

\section{Recommended Toolkit:}

- Comprehensive "Resilience Toolkit" produced by Bay Localize, 2015

- Provides all-encompassing tools to assess resilience, and to make a plan for change

Overall, the secondary research within the context of this paper exposes opportunities to further understand and develop neighbourhood resilience conceptually and concretely in regards to a neighbourhood's social and physical constructs. Grey areas, possibly less efficient strategies, and lost opportunities exist because of the complexity, constantly changing nature and ambiguity of resilience, neighbourhoods and neighbourhood resilience. There is no concrete, streamlined data or research that states what a neighbourhood is, what it means for a neighbourhood to be truly resilient, or how to address neighbourhood resilience because no neighbourhood is alike, shocks and stresses can be unpredictable, and change is the underlying constant. Thus, a more holistic approach is necessary. The secondary information also highlights the main areas in need of improvement in Ontario's Community Hubs Strategic Framework and Action Plan, 2015, how a resilience lens could be applied to the existing framework, and how a resilience framework could be integrated into the existing model. Through analysis of the secondary information and associated recommendations, the next steps should include the application of various, tailored resilience frameworks to case study locations in Ontario, with a specific focus on community hubs. This would allow researchers to further assess what tools and strategies are the most effective, which ones can be applied generally to the community hubs framework, and which areas are more beneficial when used with a customized approach. 


\subsection{DEFINITIONS}

In order to understand neighbourhood resilience, whether community hubs can address neighbourhood resilience, and whether a resilience lens can be applied to the existing Ontario Community Hubs Strategic Framework and Action Plan, 2015, the terms "neighbourhood", "resilience" and "community hub" are defined. This clarifies in detail their meaning in the context of this paper. Both "neighbourhood" and "resilience" are vague, ambiguous terms and have been used interchangeably in the field with the terms "community" and "sustainable". Community hubs also need to be defined due to their diverse and flexible nature.

For the purpose of this paper, a "neighbourhood" is defined as a group of dwellings, shops and services that can be bounded by physical barriers (can include infrastructure), is smaller than a city district, but meets the full spectrum of local needs. These include essential needs such as clean water, food and housing, as well as schools, places of employment and social services. The key point here is that neighbourhoods and their needs vary dramatically. So, in order to address issues at a local-scale, neighbourhoods need solutions that are specifically tailored to them and the people that dwell within them (the "community"). In the context of this paper, "resilience" focuses on a neighbourhood's ability to proactively respond and adapt to changes, emphasizing local capacity building, and meeting the neighbourhood's essential needs that are both physical and social in nature. The term resilience can be interpreted negatively due to its association with threats and unwelcomed events. However, this paper explores the positive and proactive resilience approaches that recognize opportunities in the face of physical and social shocks and stresses, as opposed to strict reactions to negative events. This proactive approach, includes, for example, the creation of local community groups and subgroups that focus on preventing or solving specific issues initiated by rapid change, such as food security and public health, by initiating comprehensive projects, educating the community and encouraging public participation. These neighbourhood groups design a plan, or multiple plans that aim to prevent and proactively prepare for unwanted, local stresses and shocks, and in the event that these stresses and shocks do occur, they have a grounded plan that has been informed by all members of society and is made accessible to the entire community. This ensures that the neighbourhood and its community members are not only prepared for challenges and stresses, but can thrive during and after they occur as well. Following the 
public health example, whether in the form of community food gardens at local schools or accessible educational programs provided through community services, local resilience planning on the ground-level is essential in order to meet the specific social and physical needs of a neighbourhood and its associated community. Resilience research does provide an opportunity to focus on proactive, all-encompassing, neighbourhood-scale solutions, as opposed to strict, linear reactions to negative events such as flooding or a lack of affordable housing. This opportunity is especially apparent through existing systems such as community hubs, which are explored in this paper in order to provide one possible smaller-scale solution that positively contributes to the greater context of this complex and far reaching issue.

\subsection{Neighbourhood and Community}

Many researchers have explored the definition and delineation of a neighbourhood, but there is no consensus on its definition, the definitions vary, and remain unclear (Martin, 2003, Barton, 2003, Jenks \& Dempsey, 2007, Coulton, 2012, Taylor, 2012, Uda 2016).

Neighbourhood is an ambiguous term, although it is used often in municipal policy documents such as municipal Official Plans, and is both a pertinent and important area of interest, especially in regards to practical research. In addition to its ambiguity and complexity, there also is not a clear agreement on how to define neighbourhoods spatially (Jenks \& Dempsey, 2007). Kearns and Parkinson (2001) highlight the fact that a neighbourhood is complex and its inhabitants will have varying views in regards to its relevance. What this means is that there is not a clear, sole, streamlined explanation of the term "neighbourhood", it cannot be defined in general terms, and it can be interpreted in a myriad of ways by varying people.

The term "community" is often used interchangeably with "neighbourhood", and has its own ambiguities (Jenks \& Dempsey 2007). A common definition of community emerged through MacQueen et al. (2001)'s research as “a group of people with diverse characteristics who are linked by social ties, share common perspectives, and engage in joint action in geographical locations or settings" (p.2). In this paper, "community" is used to describe only the people characteristics of a space, as expressed in Shaping neighbourhoods: a guide for health, sustainability and vitality (Barton et al., 2003), and "neighbourhood" will be used as a 
comprehensive term that includes everything from the built and natural environments to the people characteristics.

According to Toronto's Official Plan, 2015, neighbourhoods are places that foster a connection between people and their surrounding physical and social environments. They also play an important role in attracting and developing new businesses, and thus contribute to overall city growth (City of Toronto, 2015). This suggests that neighbourhoods have the capacity to generate a sense of community, and provide a foundation for reinforcing common values and goals. Municipal Official Plans across the Province include a series of goals and strategies to help guide growth in their varying, dynamic (stable and priority) neighbourhoods because they are seen as both economic drivers for the city and as community spaces where people live, work and play. Interestingly, the Provincial Policy Statement, 2014 does not address or define neighbourhoods specifically, but it refers to creating healthy communities significantly (Province of Ontario, 2014).

Kearns \& Parkinson (2001) explain that a neighbourhood operates at three varying scales, meaning that each scale has a specified purpose with certain functions, but the tendencies of each scale are general, which allows for flexibility within the system. The example provided as a result of their research addresses the fact that some neighbourhoods are less stable then others, which means that certain neighbourhoods may not be able to perform some functions, while other neighbourhoods may be able to perform functions in addition to the basic ones. For example, in regards to a high-quality neighbourhood in a high-density urban location, Kearns \& Parkinson (2001) argue that it "may provide both a place of belonging and a landscape of wider opportunity" (p.3). Kearns \& Parkinson (2001) also place emphasis on the "home area" within a neighbourhood. This area most strongly embodies the psycho-social purposes of a neighbourhood, and is defined as the spaces included within a five to ten minute walking distances from one's home. What this means is that the quality of the neighbourhood, and the residents' conceptions of the neighbourhood are best understood within the smaller unit of neighbourhood, or "home area", because they most accurately highlight the psychosocial benefits of the neighbourhood. Brower (1996) also describes the "home area" within what is considered the "good neighbourhood", meaning that the home area is meant to serve 
many functions across a broad spectrum, including creating connections with others, displaying independent and community values, participating in leisurely and recreational activities, and establishing a sense of place or belonging. These observations are useful within the context of this paper because they reinforce the need for more intimate, smaller-scale interpretations and solutions in the face of change, and when attempting to make effective recommendations that truly benefit the local communities within a neighbourhood.

A characteristic that seems to be agreed upon when defining "neighbourhood" is that a neighbourhood involves both physical and social constructs (Jenks \& Dempsey 2007, Coulton 2012, Taylor 2012, Uda, 2016). When considering the physical construct, Jenks \& Dempsey (2007) state that a neighbourhood is primarily residential, and Taylor (2012) adds that this includes more than one household. When considering the social construct, Uda (2016) argues that a neighbourhood provides an environment that fosters social interaction outside of one's home, but does not stretch as far as the city. Generally, a neighbourhood is populated by about four to five thousand people (Barton et al., 2003).

Another area that needs to be addressed in regards to defining a neighbourhood is delineating its boundaries. Barton et al. (2003), Jenks \& Dempsey (2007) and Coulton (2012) all suggest using administrative boundaries to define a neighbourhood. Uda (2016) provides alternatives to this approach, which include physical barriers, such as roads, waterways, and railways for example, infrastructure, functional spaces that provide varying services, such as schools, religious institutions or shops, a specific character that can be expressed through the built form (e.g. type of housing or main street design), and even cultural identity that is distinctive enough to create an obvious divide.

However, a counterpoint to these approaches is that administrative boundaries and physical delineations do not consider the social aspects of a neighbourhood, or the more conceptual interpretations and natural delineations that separate one neighbourhood from another. They also do not include the perceptions of the neighbourhood's residents, which have been clearly indicated as an important element in neighbourhood research and development. To clarify, the ways in which the residents experience, view, interpret and value their neighbourhoods 
contribute much more value and insight into the development, growth and improvement of a neighbourhood than any physical or administrative barrier. This is because residents know their neighbourhood the best from all aspects, which means that they can best make recommendations on how to prepare, accommodate and create plans for change effectively. This is where civic engagement plays a huge role in successful growth strategies and implementation when applying a resilience lens. With that being said, there are occasions where physical and administrative barriers do create logical divides, and thus separate neighbourhoods from one another. This is evident in some Toronto neighbourhoods, for example, which are separated by major streets (north, south, east and west with defined, unique characters), the Canadian National Railway and the Don River.

Considering the broader descriptions above of a neighbourhood as a place with both physical and social boundaries and constructs, a more refined definition of neighbourhood will be used for this paper stating that a neighbourhood is much more than a group of dwellings on a specified street delineated by administrative and physical boundaries. A neighbourhood is an area that includes both physical and social environments, including community groups, a group of dwellings, shops, services, green spaces, schools and places of employment, that meet a broad range of local needs. Emphasis is placed on meeting local needs because a neighbourhood is not as big as a district or city, but can still satisfy a full spectrum of its community's needs. This is a key indicator in the context of this paper in regards to understanding opportunities for addressing resilience.

\subsection{Resilience}

Resilience focuses on a place's ability to respond to shocks and threats while maintaining its essential functions and structures, and identity, as well as adapting and thriving in the face of continual change (ICLEI, 2015). The term is typically associated with climate change, natural disasters and disaster risk. However, in the context of this paper, resilience acknowledges social and economic issues as well, such as a lack of affordable and accessible housing, jobs, educational opportunities, financial support and green spaces, as well as disadvantaged, marginalized and underserved populations, a lack of effective, local leadership, public health issues, and gentrification and the loss of local businesses, to name a few. In order to reduce 
disaster risk and susceptibility to all risks (including social and economic), ICLEI (2015) argues that long-term, evidence-based and all-encompassing strategies are needed to take an "integrated systems approach" when addressing resilience (p.5). Notably, resilience can also be described as an alternative design and management strategy or way of thinking (Park et al. 2011, Brand \& Jax 2007).

It is hard not to acknowledge sustainability when addressing resilience, and as discussed by Brand \& Jax (2007), both terms have become ambiguous terms that define a broad range of issues and associated solutions. Bocchini et al. (2014) argue that the major difference between sustainability and resilience is that "sustainability, on the surface, assumes regular conditions - that tomorrow will be like today - whereas resilience does not" (p.3). Bocchini et al. (2014) also describe resilience in light of a place's ability to not only survive a shock or disaster, but also by its ability to recover from the harm, and the extent to which it can do so. Additionally, a highly-used definition of resilience by Walker \& Salt (2012) describes resilience with the perspective that a resilient system can absorb shocks and stresses, and reorganize and thrive during the disturbance. This means that the affected system can continue to perform essentially the same functions as it did before the unwanted disturbance and associated changes, and maintain a similar structure. Ultimately, this means that the place that is affected and is absorbing the disturbance retains its original identity, which is an important community characteristic that supports common values and ensures appropriate growth. However, when looking at evolutionary resilience, Davoudi (2012) explains that returning to a "normal" state after a disturbance is irrelevant because there is not a "normal state to return to, and the capacity of a system to adapt and change is the indicator of a truly resilient system (p.301). Considering the above findings, although there may be no "normal" state for a neighbourhood or system to return to after a disaster or disturbance, the ability to change, thrive and maintain the specific and valued neighbourhood identity is important when building resilience within a community. A resilient neighbourhood should strive to be proud of its identity, and maintain it in a way that suits the local characteristics, value and goals in order to stay socially and economically viable over a long period of time. 
The aim to reduce negative impact (injury, illness, damaged goods, death), expressed in Godschalk (2003)'s research, is an inherent consideration when defining resilience in the context of this paper. Resilience, in the traditional sense, focuses more on risk management, which is seen in many government and non-government organizations' goals to make a city or places more "resilient" (Uda, 2016). So, this traditional lens is also considered. For the purpose of this paper, the varying descriptions of the term "resilience" are considered, and "resilience" is defined as a neighbourhood's capacity to deal with future shocks, stresses, disturbances and changes that are both physical and social in nature, its ability to thrive, maintain functionality and identity during the disturbance, and its ability to continue to meet the essential needs of its community (defined by physical essential needs, such as food, water and shelter, as well as the unique social needs of each community, such as affordable housing, strong leadership, and neighbourhood communications systems).

Resilience was first explored and exposed with a scientific lens, and then in the 1960s with an ecological focus (Uda, 2016). Today, it has peaked interest in diverse fields including planning, architecture and design, environmental sciences, public health, engineering, business, technology, social sciences and of course disaster research (Bahadur et al. 2013, Norris et al. 2008), in response to increased and unpredictable changes that are occurring at local, municipal, provincial and even global scales (ICLEI, 2015). Park et al. (2013) explain that cities experience unexpected risks that have their associated failures, which in turn also have repercussions at a neighbourhood-scale. So, with a rapidly growing population in Ontario (Queen's Printer for Ontario, 2015), and thus complex or unexpected changes and risks (ICLEI, 2015), it is clear why resilience is both an intriguing and crucial area of study and implementation for Ontario planners and related professionals. A logical question that arises from a discussion about risks and risk management, as well as climate change adaptation, inquires about how these topics differ from resilience. Park et al. (2013) explain that risk management and resilience are related, but $\mathrm{Uda}$ (2016) explains that “...traditional risk management is limited to known risks of estimable probability that preferably manifest one at a time, whereas resilience can deal with any future shock or stress, including unexpected ones, as well as multiple impacts at once" (p.1). In regards to climate change adaptation, the work is related to resilience work, however, it has roots in a more traditional risk management 
approach, and the focus is solely on climate change and its associated shocks and stresses (Fünfgeld \& McEvoy 2012).

Overall, this paper will consider both the physical and social implications of resilience approaches, with a focus on the positive, proactive, unselfish, and comprehensive resilience strategies that view challenges as opportunities to prepare and support neighbourhoods, which ultimately fosters security and growth. Neighbourhood resilience has a stronger focus on the social and economic factors involved with resilience, and this will be elaborated on in chapter 4.0 .

\subsection{Community Hubs}

Community hubs are a fairly new concept, at least in Ontario and at the regulatory and planning levels, but have recently received more attention due to Ontario's Community Hubs Strategic Framework and Action Plan, 2015 that was recently released. This framework and action plan has highlighted the more formal processes involved in the creation of community hubs, including the collaboration of government agencies, service providers, stakeholders, and the community (Queen's Printer for Ontario, 2015). Overall, the main concept behind community hubs is the co-location of services in one space, which vary in regards to their type, size, organizational structure, formality and other aesthetic, spatial and functional aspects. For example, some hubs are more health-focused and offer a variety of services that support local health needs such as doctor's offices, pharmacies and therapists, whereas other hubs are more arts-focused and provide flexible work and retail studios and spaces. Community hubs can also include either temporary or permanent service providers, or both. More generally, schools, churches, libraries and seniors centres can all be considered community hubs, and community hubs can also be funded by the city or other organizations, or both.

The main commonality is that community hubs are shared spaces tailored to the specific needs of their communities, where services and programs co-exist to provide support at varying levels for all members of the community within specific neighbourhoods. A key concept here is that community hubs are not static stop-in centres focused solely on service provision, but 
shared spaces that foster community building, the interaction of community members and a place to share resources, learn and educate. Considering this broad definition of community hubs, it is clear that they involve a wide range of spaces, services and programs, and that they evolve in tandem with their communities. The focus of community hubs is not to address the needs of the community as a whole and base services on population, but to provide services and programs in one location that address the needs of a particular community, or in the case of this paper, a neighbourhood.

According to Ontario's Community Hubs Strategic Framework and Action Plan, 2015, "Community hubs provide a central access point for a range of needed health and social services, along with cultural, recreational, and green spaces to nourish community life" (Queen's Printer, 2015, p.7). In terms of location and envelope, the strategic framework and action plan explains that a community hub can be located in a variety of spaces and buildings, such as a school, library, early learning centre, government building or public spaces that can accommodate the services being provided (Queen's Printer, 2015). This is an interesting point in the context of this paper, since neighbourhoods have specific needs, and are always changing. This means that neighbourhoods require flexible services, and thus flexible spaces to provide those services in, in order to effectively meet the needs of the community. On that note, virtual community hubs do exist and offer more flexibility, however, for the purpose of this research, community hubs will refer to hubs that are located in physical buildings. Notably, in regards to physical characteristics, community hubs can also be located in highdensity urban neighbourhoods or low-density rural neighbourhoods. The key, and also the characteristic that makes the term community hub more difficult to define in a concrete sense, is that "each hub is as unique as the community it serves and is defined by local needs, services and resources” (Queen’s Printer, 2015, p.71).

Furthermore, based on the author's review of Ontario's Community Hubs Strategic Framework and Action Plan, 2015, it is evident that community hubs are intended to serve the needs of their communities, and act as places where people can provide and receive specific services, and interact with one another through learning, sharing, growing, planning, and enjoying activities (Figure 1). Another key observation is that a community hub is people- 
centred, thus it should be able to proactively make changes as necessary. This underlying structure or philosophy aligns with that of a resilience approach, which creates an interesting connection between the concepts of resilience and community hubs. This will be explored further in the following chapters of this paper.

Figure 1- What is a "Community Hub"?

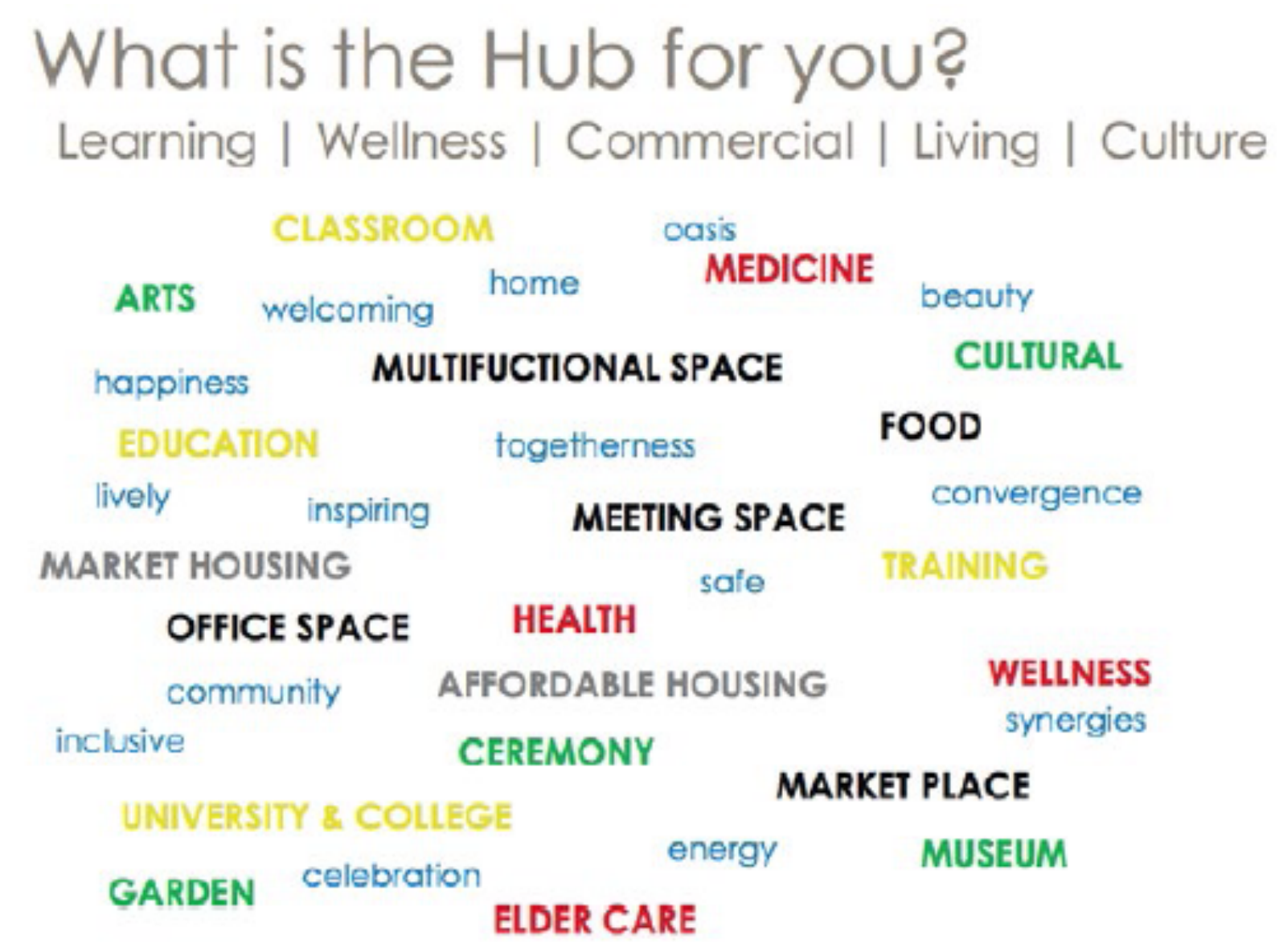

Importantly, it is clear through analysis of the existing community hubs mandate, as well as the author's empirical research, that each hub has its own strengths based on the needs of the community it is supporting, and provides a variety of services, programs and/or social and cultural activities that reflect the local community's greatest needs. Some hubs are more health-oriented, some are tailored more towards specific age groups or abilities; no community hub is like another. The key characteristic here is that the hub is designed to reflect the unique 
local needs of its community. This is affirmed by Ontario's Community Hubs Strategic Framework and Action Plan, 2015, where it states that "...It is this diversity of activity that allows community hubs to play a critical role in building economic and social cohesion in the community" (Queen's Printer, 2015, p.7).

Through Ontario's existing community hubs framework and action plan's Advisory Group research, it is clear that both political and community parties support community hubs. It is emphasized as a result of the Advisory Group's research that Ontario's diverse population of thirteen million is set to increase by thirty-one percent by 2046, and along with that increase is the existence of complex and growing needs of that diverse population (Queen's Printer for Ontario, 2015). What this means is that high-quality government and non-government services, programs and projects need to be offered and align with the growth and needs of the dynamic populations they are serving. It is also clear that both the Province and its community hubs are experiencing challenges that are demographic, economic, social and fiscal in nature, so, in the context of this paper, understanding how to support a neighbourhood's ability to thrive in times of change and stress, as well as after, has become increasingly important.

Overall, community hubs acknowledge, address and provide solutions to social, demographic, economic, and fiscal challenges that arise in neighbourhoods, and provide a myriad of benefits. Whether in the form of school-community partnerships that support the need for, and enhance the quality of, learning and teaching opportunities, improved access to more efficient, sustainable and comprehensive services, the collaboration and co-location of various community agencies that strengthen the system when working together, or social return on investment where money can be saved in other sectors through integrated service delivery models, community hubs provide more accessibility and better outcomes for their communities through increased connectivity, and thus enhanced solutions and service provision.

Although a limitation exists in regards to the fact that little evidence-based research exists to support community hubs, the Social Return on Investment (SROI) model is being used to measure the social value of community hubs in relation to the resources invested into the 
model (Queen's Printer, 2015). In addition to the emerging SROI model, the Advisory Group's research for Ontario's Community Hubs Strategic Framework and Action Plan, 2015, and the author's empirical research, the advantages of community hubs are validated based on hundreds of reviews from diverse individuals and organizations, site visits and interviews. To further support this, Karen Pitre, the Special Advisor for Ontario's Community Hubs Strategic Framework and Action Plan, 2015, explains that through her team's efforts to develop the framework and action plan, it became clear that in Ontario there is a lot of vitality, creativity and leadership, at the local or community level, associated with community hubs. Most importantly, the community hubs are being used strategically to provide accessible services at the local level that are unique and tailored to the specific areas that they are serving (Queen's Printer for Ontario, 2015).

Pitre's emphasis on the local-level, or neighbourhood-scale, highlights the need for resilience research within a more intimate scope versus the current citywide and global scales. Overall, through this research and firsthand experience, it is emphasized that both economic and social benefits arise from the creation of community hubs, which are not only "vibrant centres of community life" (Queen's Printer, 2015, p.9), but a tool that can be used as a stable foundation during and after neighbourhood changes, shocks and threats of all kinds. 


\subsection{NEIGHBOURHOOD RESILIENCE}

\subsection{Understanding Resilience at a Neighbourhood-scale}

Fraser Basin Council et al. (2015) recognize that "change is hard at the best of times, and even harder at the worst of times" (p.4), which clearly highlights the need for an effective resilience approach and stronger resilience skills. In line with this broader statement addressing resilience, the aim of neighbourhood resilience strategies is to strengthen the cohesion and capacity of neighbourhoods to respond to social, climate, resource, and economic challenges now and in the future. However, neighbourhood resilience means much more than having a prepared response to an emergency. Yes, neighbourhood resilience prepares for the unexpected, but it also strengthens existing systems (social and physical), and proactively aims to prevent disasters or stresses from happening in the first place (Uda, 2016). This can take the form of a community establishing a strong leader that is supported by organized groups and committees. These groups focus not only on meeting specific essential social and physical needs of their neighbourhood, but also preparing an emergency plan and sharing it with all members of the community. Civic engagement and education, including all members of the neighbourhood, is a key component that contributes to a positive and successful resilience approach because residents know their neighbourhood and its needs best, and can provide a full spectrum of knowledge and insight. When residents are engaged and are encouraged to focus on their connection to place, they get to experience positive action firsthand, and more clearly understand that change at the local level is feasible, but is still farreaching and can have great impact (Fraser Basin Council et al., 2015). This can create a lot of positive energy, enthusiasm and fellowship within a neighbourhood, especially because the residents are empowered and encouraged to collaborate and contribute.

Another proactive resilience approach can take form through establishing community gardening groups that provide access to local, healthy food, help clean the air, provide public spaces for everyone to participate in recreational and learning activities, and help to prevent flooding during heavy rainfall. Proactive resilience strategies also include the implementation of accessible services and education, especially for marginalized groups or groups with greater needs, which can focus on everything from affordable housing and financial assistance to public health or childcare services. The overall goal is for the neighbourhood to thrive before, 
during and after shocks and stresses, and to prevent disasters from happening, if possible, in the first place (Fraser Basin Council et al., 2015, Uda, 2016). If shocks and stresses cannot be prevented, an alternative means to meet essential needs must be established (Uda, 2016) such as establishing a community food garden and food co-op, as opposed to just relying on a food bank. Neighbourhood resilience approaches, strategies and main findings from across Canada are discussed in more detail in the next chapter 5.0 Case Studies Analysis.

Kearns \& Parkinson (2001) emphasize that "neighbourhood change is proving unpredictable and resulting in ever-wider gaps in fortune and prosperity between places within single regions and countries" (p.1). BC's Capital Regional District has a proactive response to this reality by implementing a pilot project that establishes a local community investment fund that aims to support affordable housing and community enterprise development. Through this approach, the Province's, as well as local organizations' interest in encouraging allencompassing, place-based change, was reinforced because this approach is most effective at the local level (Fraser Basin Council et al., 2015). In most cases, resilience is often interpreted as a place's ability to respond to a disaster or crisis quickly and continue to thrive (Fünfgeld \& McEvoy 2012), but as aforementioned, and as Fraser Basin Council et al. (2015) and Uda (2016) confirm, the focus needs to be not only on disaster response, but on creating a community or communities within neighbourhoods that are strong and cohesive, and proactively prevent future threats. Again, this can take the form of building a common sense of community, which in turn strengthens social ties and connections to people and place, supporting and including vulnerable populations, and addressing inequities through introducing accessible services and programs.

The neighbourhood-scale has been chosen as the scope for this paper because although resilience work is starting to appear on municipalities' radar, it is predominantly explored within a larger scope. According to Uda (2016), a lack of regulation and guidelines, and a lack of public knowledge and demand are the primary reasons why neighbourhood resilience work has not thoroughly been explored and shared to this date. Neighbourhoods and their communities today face a complex range of social, environmental, and economic challenges. Many communities are seeing that new ways of addressing these challenges are needed, 
especially approaches that acknowledge the interrelated nature of these issues. A focus on neighbourhood resilience can provide that lens and framework. Henderson (2010), in addition to supporting a neighbourhood-scale approach, further emphasizes the immediacy of addressing neighbourhood resilience on all scales at once, especially in regards to climate change and its far-reaching impacts. Fraser Basin Council et al. (2015) builds off of Henderson's point, expressing that when a resilience lens is used, and systemic relationships that exist within the city are understood, both chronic and acute issues are addressed not just with long-term solutions that focus solely on one specific issue, but rather solutions that address many different issues at once.

So, it is clearly time to start understanding and developing resilience strategies at the local level immediately for the system of resilience work to be effective. A focus on neighbourhood resilience means understanding and addressing the fact that neighbourhoods and their communities are dynamic and are always changing. With that being said, neighbourhoods also have existing strengths, systems, resources and abilities, including social capital (mutual trust, participation, and social norms and networks) that can be enhanced to proactively address issues that are both physical and social in nature (Australian Social Inclusion Board, 2009), such as vulnerable populations and extreme weather. In addition to understanding a neighbourhood resilience application in planning and related fields, it is important to address what neighbourhood resilience approaches mean for all levels of government. A resilience approach at the neighbourhood-scale requires neighbourhoods and their associated communities to create a new collaborative approach with local, regional and provincial governments. Bach et al. (2010) speak to policy challenges that would be necessary to support community resilience and argue that resilience encourages a neighbourhood to build off of foundations, systems and local relationships that already exist, while simultaneously preparing for risks using local knowledge. The end result is that the neighbourhood and communities within it will be prepared in the face of an emergency, and be able to thrive during and after it. Notably, there is an opportunity here for the central government to support public engagement in a way that is effective as well, and take an approach that reaches farther than just supporting new social programs. The relationship between the governing body, or bodies, and the community must be strengthened and supported by a mutual resilience philosophy and 
common goals (Bach et al., 2010). There is a real opportunity here for a comprehensive approach that involves the support and knowledge of government and non-government organizations. This is necessary when it comes to creating relationships with local neighbourhood groups and organizations that are looking to strengthen neighbourhood resilience by building on existing local knowledge and resources.

The next chapter outlines ten case studies and major findings that provide examples of what it means for a neighbourhood to be truly resilient, and what resilience actions, approaches, and frameworks are currently being established and are successful at the neighbourhood-scale across Canada. These findings create a foundation that can provide recommendations for other neighborhoods looking to address resilience, as well as opportunities and areas in need of improvement. 


\subsection{CASE STUDIES ANALYSIS AND MAIN FINDINGS}

\subsection{Case Studies Overview}

A review of case studies that focus on addressing neighbourhood resilience in Canada produces several observations and recommendations for other neighbourhoods looking to become more resilient in both a physical and social sense, in addition to the aforementioned information drawn from the literature review. Case studies include more in-depth analysis such as the research conducted by Colten (2010) on Charleston, South Carolina, Gulfport, Mississippi and Memphis, Tennessee, resilience pilot projects in Toronto, the T'Souke First Nations on Vancouver Island, British Columbia, the Sangudo Investment Co-op in Alberta, a specific street called McKaskill Street in Victoria, British Columbia, a project called Neighbourhood Alive! in Manitoba and an impact analysis of London, Ontario. The case study focus, description, main findings and results are highlighted in Table 1, and provide insight for other communities looking to address, improve or create resilience programs in their neighbourhoods. Tables 2 and 3 support the research in case study \#7, providing an example of an impact analysis and essential needs analysis for a neighbourhood in London, Ontario.

Table 1- Case Studies Analysis and Main Findings

\begin{tabular}{|l|l|l|}
\hline CASE STUDY & DESCRIPTION & MAIN FINDINGS \\
\hline $\begin{array}{l}\text { 1. Charleston, South } \\
\text { Carolina, Gulfport, } \\
\text { Mississippi, and } \\
\text { Memphis Tennessee } \\
\text { Source: Colten, } 2015\end{array}$ & $\begin{array}{l}\text { Distinctly diverse communities } \\
\text { explored in regards to their } \\
\text { degree of community } \\
\text { resilience (vary in size, } \\
\text { demographic and economic } \\
\text { characteristics, as well as } \\
\text { associated hazards) }\end{array}$ & $\begin{array}{l}\text { Five broad categories are } \\
\text { recommended to improve } \\
\text { neighbourhood resilience: }\end{array}$ \\
& $\begin{array}{l}\text { Aim of research: } \\
\text { To promote civic engagement and political spectrum of } \\
\text { social } \\
\text { a community } \\
\text { - essential resilient attributes } \\
\text { were found imbedded in } \\
\text { vulnerable populations' social }\end{array}$ \\
& $\begin{array}{l}\text { expertise and b) local concerns } \\
\text { *The primary research is } \\
\text { - vulnerable groups, and the ones } \\
\text { combined with practice at the greatest need, need to be } \\
\text { integrated and considered in the } \\
\text { planning phases } \\
\rightarrow \text { this helps to fill any gaps, and }\end{array}$ \\
\hline
\end{tabular}


ensures that everyone has

knowledge about the plans and

resources available

(2) Buy-in from local leaders and effective leadership

- neighbourhoods require their own refined hierarchy of

allocated responsibilities and roles, which includes a highlevel of cooperation, communication and responsiveness

- leaders must be efficient in responding to challenges at all levels

- a strong leader organizes, communicates with, and supports community teams that exist to support the overall neighbourhood resilience system. - teams should be qualified and experienced if possible - leaders and teams should have thorough background knowledge on past challenges, changes and events

(3) Communication and coordination among many interdependent organizations

- important stages: anticipate, reduce, respond, and recover - good-quality communication and coordination must be maintained throughout the stages - include social networks, both formal and informal in nature, as well as hard systems before the disturbances actually occur, so that the system can be effective before, during and after the shocks, stresses and changes - include all members of the community

(4) Ongoing preparation and training that extends from 


\begin{tabular}{|c|c|c|}
\hline & & $\begin{array}{l}\text { anticipation and reduction, } \\
\text { through response, to recovery } \\
\text { - demands continuous } \\
\text { preparation and training, which } \\
\text { extends to all areas of the } \\
\text { population } \\
\text {-revisit, reassess and update } \\
\text { plans } \\
\text { - establish an effective } \\
\text { communication system where } \\
\text { knowledge can be shared to new } \\
\text { leaders and teams, and then to } \\
\text { the rest of the community } \\
\text { - regular resilience training, } \\
\text { exercises and drills } \\
\text { - this approach increases } \\
\text { awareness and strengthens } \\
\text { relationships } \\
\text { (5) Flexibility in plans to } \\
\text { enable a more agile response to } \\
\text { the unexpected } \\
\text { - extreme events and } \\
\text { unwelcomed surprises can } \\
\text { exceed expectations and have } \\
\text { greater impact that what was } \\
\text { anticipated, so a truly resilient } \\
\text { neighbourhood must plan and } \\
\text { prepare for the unexpected } \\
\text { - plans cannot stand alone, and } \\
\text { must work simultaneously with } \\
\text { flexible leaders, teams, } \\
\text { organizations, emergency- } \\
\text { response professionals, } \\
\text { volunteers and citizens }\end{array}$ \\
\hline $\begin{array}{l}\text { 2. Faith \& the } \\
\text { Common Good- } \\
\text { Resilience Pilot } \\
\text { Projects in Toronto } \\
\text { Source: City of } \\
\text { Toronto, } 2015 \text { \& } \\
\text { Livegreen Toronto, } \\
\text { 2015) }\end{array}$ & $\begin{array}{l}\text { Aim of research: } \\
\text { to understand and explore the } \\
\text { extent to which faith } \\
\text { communities can support } \\
\text { resilience at the local level/ } \\
\text { neighbourhood-scale in the } \\
\text { face of extreme weather } \\
\text { conditions }\end{array}$ & $\begin{array}{l}\text { Eight resilience pilot projects, } \\
\text { all diverse in nature, across } \\
\text { Toronto: } \\
\text { - both physical and social site } \\
\text { conditions were researched } \\
\text { (main sites and the areas } \\
\text { surrounding them) } \\
\text { - paid particular attention to civic } \\
\text { engagement, with a focus on } \\
\text { training, workshops and resource }\end{array}$ \\
\hline
\end{tabular}




\begin{tabular}{|c|c|c|}
\hline & & $\begin{array}{l}\text { development, which all proved to } \\
\text { have major benefits } \\
\text { - major lessons uncovered from } \\
\text { these projects prove that faith } \\
\text { communities present the } \\
\text { opportunity to serve their } \\
\text { neighbourhoods' and associated } \\
\text { communities' specific needs } \\
\text { - action plans and next steps } \\
\text { cover a broad range of issues } \\
\text { including, but not limited to: } \\
\text { understanding liability, security } \\
\text { and financial implications, } \\
\text { community partnership } \\
\text { participation, emergency } \\
\text { roundtable meetings, establishing } \\
\text { disaster plans and disaster } \\
\text { education and training, } \\
\text { supporting the capacity to serve } \\
\text { members of the public }\end{array}$ \\
\hline $\begin{array}{l}\text { 3. T'Souke First } \\
\text { Nation- Local } \\
\text { Economies that } \\
\text { Support } \\
\text { Neighbourhood } \\
\text { Resilience } \\
\text { Source: T'Souke First } \\
\text { Nation, } 2016\end{array}$ & $\begin{array}{l}\text { Aim of research: to focus on } \\
\text { energy security and sustainable } \\
\text { actions in order to ensure a } \\
\text { sustainable future for their } \\
\text { community }\end{array}$ & $\begin{array}{l}\text { Employs a strategy including } \\
\text { four interconnected priorities: } \\
\text { autonomy, food self-sufficiency, } \\
\text { cultural renaissance, and } \\
\text { economic development } \\
\text { - solar PV and solar thermal were } \\
\text { installed on various Band } \\
\text { buildings by members that had } \\
\text { been trained as solar installers } \\
\text { - the training program worked to } \\
\text { build on the community's } \\
\text { existing oral traditions } \\
\text { - T'Souke First Nation sells } \\
\text { clean oil to BC Hydro and has } \\
\text { also installed approximately } \\
\text { twelve-hundred solar hot water } \\
\text { heaters with an adjacent } \\
\text { municipality } \\
\text { - major results of this resilience } \\
\text { work is that they can meet their } \\
\text { own energy needs, while } \\
\text { supporting the local economy } \\
\text { and maintaining their strong } \\
\text { community identity }\end{array}$ \\
\hline
\end{tabular}




\begin{tabular}{|c|c|c|}
\hline $\begin{array}{l}\text { 4. Sangudo } \\
\text { Opportunity } \\
\text { Development } \\
\text { Cooperative- Local } \\
\text { Economies that } \\
\text { Support } \\
\text { Neighbourhood } \\
\text { Resilience } \\
\text { Source: Government of } \\
\text { Alberta, } 2016\end{array}$ & $\begin{array}{l}\text { Aim of research: To establish } \\
\text { a resilience approach in a rural } \\
\text { environment that involves four } \\
\text { hundred citizens creating a } \\
\text { community investment } \\
\text { cooperative. It was initiated so } \\
\text { that they did not have to waste } \\
\text { time waiting for town council } \\
\text { and other governing agencies } \\
\text { to address issues such as low } \\
\text { property values and declining } \\
\text { enrollment. }\end{array}$ & $\begin{array}{l}\text { Implemented a Community } \\
\text { Investment Cooperative } \\
\text { Strategy: } \\
\text { - involved investing in the } \\
\text { revitalization of empty buildings } \\
\text { and providing local services in } \\
\text { their neighbourhoods, which } \\
\text { included the pooling of resources } \\
\text { - included four areas that created } \\
\text { more resilient neighbourhoods: } \\
\text { (i) community vision, (ii) trusted } \\
\text { leadership, (iii) an economic } \\
\text { strategy and (iv) being compelled } \\
\text { by a wider agenda for change. } \\
\text { - so successful that five similar } \\
\text { pilot projects have been } \\
\text { supported by the Province of } \\
\text { Ontario } \\
\text { - as a result, the Community } \\
\text { Social Planning Council of } \\
\text { Greater Victoria in British } \\
\text { Columbia's citizen group and } \\
\text { associated organizations } \\
\text { implemented a local community } \\
\text { investment fund that focuses on } \\
\text { community enterprise } \\
\text { development and affordable } \\
\text { housing }\end{array}$ \\
\hline $\begin{array}{l}\text { 5. McKaskill Street, } \\
\text { Victoria, British } \\
\text { Columbia- } \\
\text { Addressing Social } \\
\text { Capital through } \\
\text { Transition Streets } \\
\text { Source: Transition } \\
\text { Victoria, } 2016\end{array}$ & $\begin{array}{l}\text { Aim of research: } \\
\text { reducing energy and resource } \\
\text { use through the combined } \\
\text { efforts of neighbourhood } \\
\text { groups } \\
\text { - part of the Transition Streets } \\
\text { pilot project } \\
\text { - neighbours that live on } \\
\text { McKaskill Street participated } \\
\text { in, and were successful in, } \\
\text { reducing energy significantly }\end{array}$ & $\begin{array}{l}\text { Provides an opportunity to } \\
\text { address resilience at the } \\
\text { neighbourhood-scale through a } \\
\text { guided curriculum that was } \\
\text { developed over the period of } \\
\text { several months: } \\
\text { - focus on local food, water use, } \\
\text { energy use, transportation, and } \\
\text { waste/ consumption } \\
\text {-advises community members to } \\
\text { address the actions they deem } \\
\text { necessary to take in each area in } \\
\text { order to address these focus areas } \\
\text { - most significant lesson is the }\end{array}$ \\
\hline
\end{tabular}




\begin{tabular}{|c|c|c|}
\hline & & $\begin{array}{l}\text { importance of building } \\
\text { relationships amongst } \\
\text { neighbours, creating } \\
\text { conversations, generating ideas } \\
\text { and putting them into action as a } \\
\text { collective group with common } \\
\text { goals } \\
\text { Major highlights/results from } \\
\text { nine households: } \\
\text { - } 4 \text { houses have had major } \\
\text { insulation upgrades } \\
\text { - } 5 \text { low-flow toilets installed plus } \\
\text { high- efficiency shower heads } \\
\text { - more gardening is done by } \\
\text { everyone, and gardens and tools } \\
\text { are being shared } \\
\text { - group purchasing of local } \\
\text { organic food } \\
\text { - work parties for major and } \\
\text { minor tasks } \\
\text { - telephone poles have been } \\
\text { "decorated" } \\
\text { - skills are being shared } \\
\text { - overall, a sense of community } \\
\text { is now established } \\
\text { *high social capital is a main } \\
\text { indicator of resilient } \\
\text { neighbourhoods and their } \\
\text { associated communities }\end{array}$ \\
\hline $\begin{array}{l}\text { 6. Neighbourhoods } \\
\text { Alive! Manitoba- } \\
\text { Building } \\
\text { Neighbourhood } \\
\text { Resilience } \\
\text { Source: Province of } \\
\text { Manitoba, } 2015\end{array}$ & $\begin{array}{l}\text { Aim of research: to support } \\
\text { specific neighbourhoods and } \\
\text { their various community } \\
\text { development initiatives, such } \\
\text { as; housing, community } \\
\text { recreation, crime prevention, } \\
\text { training, and education } \\
\text { - accomplished this through } \\
\text { funding streams designed to } \\
\text { support the neighbourhood's } \\
\text { goals }\end{array}$ & $\begin{array}{l}\text { Focuses on strengthening } \\
\text { neighbourhoods through a } \\
\text { citizen and community-led, } \\
\text { place-based approach: } \\
\text { - creates a strong foundation for } \\
\text { meeting long-term social and } \\
\text { economic development goals } \\
\text { - made possible through the } \\
\text { Community Renewal Act, which } \\
\text { approves community renewal } \\
\text { plans and ensures that they } \\
\text { receive high-level leadership and }\end{array}$ \\
\hline
\end{tabular}




\begin{tabular}{|c|c|c|}
\hline & & $\begin{array}{l}\text { support } \\
\text { - these plans involve a discourse } \\
\text { between residents and a } \\
\text { Community Renewal Advisory } \\
\text { Committee, including } \\
\text { community- based stakeholders } \\
\text { - community engagement } \\
\text { provides valuable ideas and } \\
\text { information } \\
\text { - community partners should aim } \\
\text { to build on existing strengths and } \\
\text { knowledge, acknowledging } \\
\text { specific needs, conditions and } \\
\text { goals }\end{array}$ \\
\hline $\begin{array}{l}\text { 7. London Ontario- } \\
\text { Analysing } \\
\text { Neighbourhood } \\
\text { Resilience \& } \\
\text { Developing a } \\
\text { Framework } \\
\text { Source: Uda, } 2016 \\
\text { See Tables } 2 \text { and } 3 \text { for } \\
\text { an example of an } \\
\text { impact and essential } \\
\text { needs for a } \\
\text { neighbourhood in } \\
\text { London, Ontario } \\
\text { (energy system in the } \\
\text { face of a heat wave } \\
\text { risk) }\end{array}$ & $\begin{array}{l}\text { Aim of research: } \\
\text { To develop a resilience } \\
\text { framework at the } \\
\text { neighbourhood-scale by } \\
\text { answering: } \\
\text { a) what are the essential needs } \\
\text { of a community (people in a } \\
\text { neighbourhood)? } \\
\text { b) what are the future risks } \\
\text { applicable to the } \\
\text { neighbourhood? } \\
\text { - this helps to create a } \\
\text { framework that ensures that a } \\
\text { neighbourhood is always } \\
\text { meeting the essential needs of } \\
\text { its community }\end{array}$ & $\begin{array}{l}\text { Essential needs are outlined, as } \\
\text { well as what is required to } \\
\text { meet these needs: } \\
\text { - Uda (2016): clean air and } \\
\text { water, food, sanitation, shelter } \\
\text { and basic furnishings, security, } \\
\text { health, privacy, space, } \\
\text { communication, transportation } \\
\text { (focuses more on physical needs) } \\
\text { - Maslow (1947)'s hierarchy of } \\
\text { needs (focuses more on social } \\
\text { needs): physiological needs, and } \\
\text { the need for safety, love, self- } \\
\text { esteem as well as the esteem of } \\
\text { others and self-actualization } \\
\text { - Canadian International } \\
\text { Development Agency (1997): } \\
\text { primary health care, basic } \\
\text { education, family planning and } \\
\text { reproductive health care, food } \\
\text { and nutrition, emergency } \\
\text { nutrition, water and sanitation, } \\
\text { shelter, humanitarian assistance, } \\
\text { and integrated basic human } \\
\text { needs }\end{array}$ \\
\hline
\end{tabular}




\begin{tabular}{|c|c|c|}
\hline 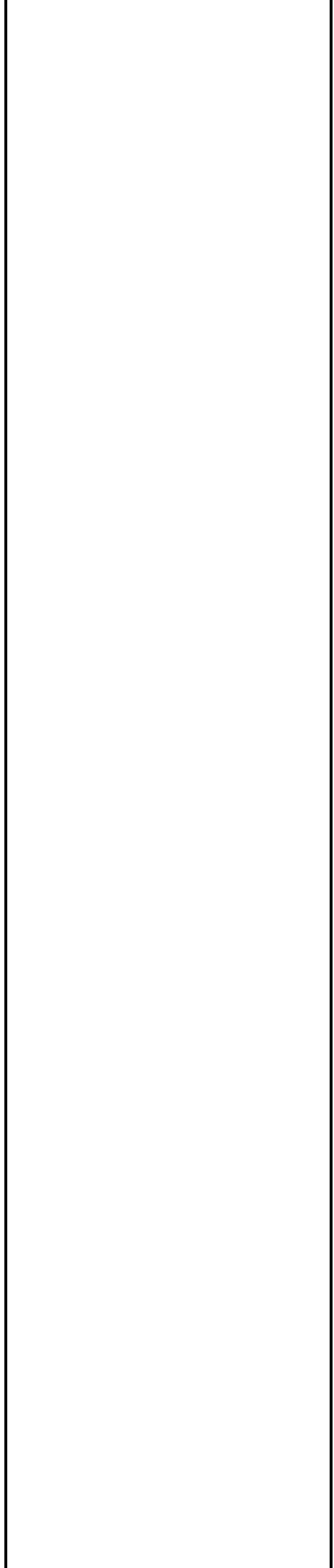 & & $\begin{array}{l}\text { Future Risks (Collier et al., } \\
\text { 2014, Uda, 2016) grouped in } \\
\text { seven main categories: } \\
\text { - resources, infrastructure, } \\
\text { environment, government, social, } \\
\text { technology and other (including } \\
\text { "the unexpected") } \\
\text { - heavy focus on climate change } \\
\text { risks, such as heat waves, } \\
\text { extreme weather, species and } \\
\text { ecosystem changes and the } \\
\text { spread of disease } \\
\text { - other risks: resource shortages, } \\
\text { failing infrastructure, breakdown } \\
\text { of economic, political and social } \\
\text { systems, and conflict, terrorism } \\
\text { and crime } \\
\text { Challenges \& } \\
\text { Recommendation: } \\
\text { - neighbourhoods are complex } \\
\text { and have various future risks } \\
\text { - neighbourhood systems are part } \\
\text { of the infrastructure that is } \\
\text { included within the } \\
\text { neighbourhood's boundaries or } \\
\text { penetrates the boundary (they are } \\
\text { not the same as municipal } \\
\text { systems, but are a "subset of the } \\
\text { municipal and regional systems") } \\
\text { - there is a need to conduct } \\
\text { - neveral resilience analyses as } \\
\text { comboural environment, healthy } \\
\text { gas, fuel, water supply, food, } \\
\text { sewage, stormwater, building } \\
\text { - establish a specific } \\
\text { neighbourhood system and focus } \\
\text { on it (e.g. water supply system) } \\
\text { in order to define the scope of } \\
\text { analysis }\end{array}$ \\
\hline
\end{tabular}




\begin{tabular}{|c|c|c|}
\hline 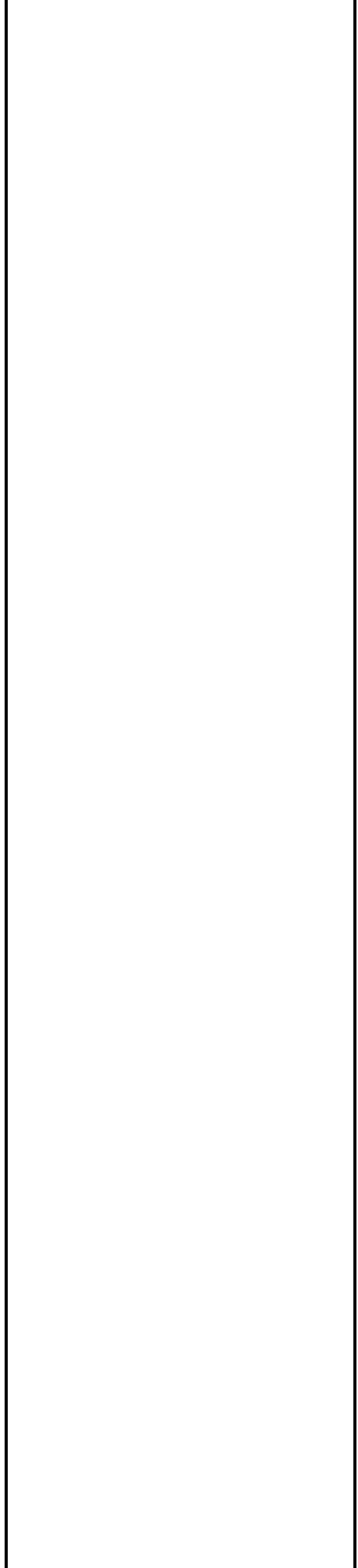 & & $\begin{array}{l}\text { shell, waste removal, police \& } \\
\text { firefighting, healthcare \& } \\
\text { emergency, communications, } \\
\text { transportation and essential } \\
\text { products supply } \\
\text { - Uda (2016) also encourages the } \\
\text { description of the systems' } \\
\text { components that are necessary to } \\
\text { meet essential needs } \\
\text { How to Proceed } \\
\text { - explore what the impacts of the } \\
\text { future risks might be, and how } \\
\text { severe they will be } \\
\text { - explore solutions that can } \\
\text { prevent or minimize these } \\
\text { impacts } \\
\text { - explore alternative means to } \\
\text { meet needs, and if this is not } \\
\text { possible, specify “coping } \\
\text { actions" (sometimes these are not } \\
\text { effective, so alternative solutions } \\
\text { and actions are ideal) } \\
\text { Understanding Two Levels of } \\
\text { Resilience: } \\
\text { 1) enhancing and continuing to } \\
\text { improve the resilience of a } \\
\text { particular neighbourhood system } \\
\text { 2) In the event of a failed system, } \\
\text { ensuring that the neighbourhood } \\
\text { as a whole is resilient } \\
\text { Application of Framework to } \\
\text { London, Ontario } \\
\text { - Uda (2016) provides an impact } \\
\text { and essential needs analysis for a } \\
\text { neighbourhood's energy system } \\
\text { in the face of a heat wave risk } \\
\text { - once the tables are filled out } \\
\text { based on the above model, } \\
\text { recommendations can be made }\end{array}$ \\
\hline
\end{tabular}


Table 2-Impact Analysis for a Neighbourhood in London, Ontario (energy system in the face of a heat wave risk)

\begin{tabular}{|l|l|l|l|}
\hline Column 1 & Column 2 & Column 3 & Column 4 \\
\hline Future risks & $\begin{array}{l}\text { Impacts on } \\
\text { neighbourhood system } \\
\text { (e.g., energy system) }\end{array}$ & $\begin{array}{l}\text { Action to prevent or } \\
\text { minimize impact }\end{array}$ & $\begin{array}{l}\text { Actions to deal with } \\
\text { impact }\end{array}$ \\
\hline heat waves & $\begin{array}{l}\text { can overheat cables, } \\
\text { equipment }\end{array}$ & $\begin{array}{l}\text { ensure all cables \& } \\
\text { equipment can } \\
\text { withstand high } \\
\text { temperatures }\end{array}$ & \\
\cline { 2 - 4 } & $\begin{array}{l}\text { air conditioning use } \\
\text { increase } \rightarrow\end{array}$ & & $\begin{array}{l}\text { be able to function } \\
\text { without external grid }\end{array}$ \\
\cline { 2 - 4 } & $\begin{array}{l}\text { undesirable to run } \\
\text { combined heat/power unit } \\
\text { as it would add to heat }\end{array}$ & $\begin{array}{l}\text { be able to meet } \\
\text { electricity needs } \\
\text { without combined } \\
\text { heat/power in summer }\end{array}$ \\
\hline <insert other risks> & $\ldots$ & $\ldots$ & ... \\
\hline
\end{tabular}

Table 3-Essential Needs Analysis for a Neighbourhood in London, Ontario (energy system in the face of a heat wave risk)

\begin{tabular}{|l|l|l|l|l|}
\hline Column 1 & Column 2 & Column 3 & Column 4 & Column 5 \\
\hline Essential Needs & $\begin{array}{l}\text { how essential } \\
\text { need would be } \\
\text { met currently if } \\
\text { neighbourhood } \\
\text { system failed (i.e., } \\
\text { coping action) }\end{array}$ & $\begin{array}{l}\text { Is the current } \\
\text { coping action } \\
\text { satisfactory? If } \\
\text { "no," go to } \\
\text { Column 4. }\end{array}$ & $\begin{array}{l}\text { additional coping } \\
\text { action }\end{array}$ & $\begin{array}{l}\text { Is coping action } \\
\text { sufficient? If } \\
\text { "no," improve on } \\
\text { Table 2.6 Column } \\
\text { 3. }\end{array}$ \\
\hline shelter cooling & $\begin{array}{l}\text { by passive design } \\
\text { features (lots of } \\
\text { insulation, } \\
\text { shading); diesel } \\
\text { generator for } \\
\text { mechanical cooling }\end{array}$ & no & $\begin{array}{l}\text { neighbourhood } \\
\text { cooling centre at } \\
\text { retirement home (if } \\
\text { microgrid working) } \\
\text { or off-grid } \\
\text { community centre } \\
\text {... }\end{array}$ & yes \\
\hline $\begin{array}{l}\text { <insert other } \\
\text { needs> }\end{array}$ & $\cdots$ & $\ldots$ & $\cdots$ \\
\hline
\end{tabular}

\subsection{Case Studies Summary}

Major findings from the case studies highlight the importance of inclusive planning, creating strong relationships, sharing knowledge amoung all community members, and establishing strong leadership in order to prepare for changes, risks and threats, as well as meeting essential needs afterwards. Leaders and teams should have thorough background knowledge on past challenges, changes and events in order to respond, recover and thrive with success. 
Additionally, In order to be truly resilient, opportunities for everyone to learn and engage, as well as mitigation and response training need to be provided. This approach increases awareness, strengthens relationships and ensures that all leaders, teams, organizations and stakeholders are informed, engaged, prepared and working cooperatively and efficiently.

An interesting approach is also uncovered through Sangudo's Opportunity Development Cooperative, which is used to support the local economy and was initiated so that they did not have to waste time waiting for town council and other governing agencies to address issues such as low property values and declining enrollment. Another key takeaway from this case study is that the level of social capital is a main indicator of resilient neighbourhoods and their associated communities. This is further explained by Wilding (2011) who states that the end result is that ideas, actions and innovations can be generated and shared across varying networks, and that citizens from all backgrounds and statuses can share and learn from each other. Furthermore, community engagement rises to the forefront again through the Neighbourhoods Alive! Initiative in Manitoba in regards to idea generation. This means that the community provides valuable ideas and information that can contribute to the revitalization of neighbourhoods and community partners can build on existing systems. Establishing a citizen and community-led, place-based approach like this one provides funding and planning systems and networks while also supporting the community's ongoing goals. Finally, Uda (2016)'s neighbourhood-scale resilience framework should be paired with her interdependence analysis. An interdependence analysis can help to prioritize the multiple resilience analyses that will be most effective for a specific neighbourhood. The interdependence analysis explores a neighbourhood's systems' dependencies at the neighbourhood-scale, not the municipal or regional-scales. A key decision at this scale is to not include neighbourhood systems (e.g. neighbourhood sewage system) that are not dependent on electricity or natural gas (electricity and natural gas at the municipal sewage treatment plant). This is because the sewage treatment plant is not in the neighbourhood, and the dependencies rely on the systems within the neighbourhood. Thus, as Uda (2016) confirms, the concern that arises is what can and cannot be done at the neighbourhood-scale. It is also clear that Uda (2016)'s research primarily focuses on the climate-related and physical risks associated with resilience strategies, so this framework should also incorporate the 
socially grounded recommendations. This point further demonstrates the complexity of neighbourhoods, the need for multiple resilience analyses (system analyses) that can help to prioritize actions, and the need for a comprehensive, place-based approach that involves all of the community. This will ensure that the priorities chosen are effective in meeting each neighbourhood's specific needs.

Overall, it is clear from the case study findings that resilience strategies at the neighbourhoodscale are diverse, may focus on one or more specific physical and social needs, and must involve a comprehensive, civic engagement and place-based approach. A neighbourhood's specific needs that are met presently and that are planned for in the future ultimately support the overall resilience capacity of the neighbourhood. Communities within neighbourhoods should continue to build on their existing systems in order to adapt to the changes and ensure future success, and have a strong focus on public participation that encourages both teaching and learning environments. As aforementioned, this characteristic is also evident in the structure of community hubs. Thus, before exploring possible neighbourhood resilience frameworks, the next chapter will explore the opportunities for Ontario's Community Hubs Strategic Framework and Action Plan, 2015 to address resilience at a neighbourhood-scale. 


\subsection{EXPLORING ONTARIO'S COMMUNITY HUBS STRATEGIC FRAMEWORK AND ACTION PLAN'S CAPACITY TO ADDRESS NEIGHBOURHOOD RESILIENCE}

Premier Wynne envisions Ontario as a place that provides the best environments for its neighbourhoods and associated communities (Queen's Printer for Ontario, 2015), which is why the Province has recently supported community hubs with more vigour. As a result of this vision, Karen Pitre was selected as the Special Advisor to guide the adaptation of existing public properties into community hubs, and was commissioned to answer how the Province could support successful community hub development (Queen's Printer for Ontario, 2015), which in turn supports the needs of the community. On April 8, 2015, Pitre gained the support of a nine-person Advisory Group and a Cabinet Office Secretariat to thoroughly research and review relevant provincial policies and best practices, including over seventy stakeholder meetings, in order to produce a framework for this mandate. The overall level and quality of response, as well as enthusiasm, was high. Although both the Province and communities that participated in the research understand that community hubs promote both social and economic benefits and are dynamic centres of activity (Queen's Printer for Ontario, 2015), many barriers and constraints are evident in regards to the successful development and growth of community hubs. One of those barriers is the fact that the associated policies and processes are often fragmented, do not support an effective community hub system because they are complicated, and focus more on ministry requirements than the community's specific needs (Queen's Printer for Ontario, 2015), and thus the outcomes experienced by the community itself.

As a result, the research behind Ontario's Community Hubs Strategic Framework and Action Plan, 2015 focuses on ensuring that those barriers are going to be removed and that community hubs can effectively evolve from the adaptation of public properties moving forward. Fortunately, in addition to high quality responses from both government and nongovernment groups, the groups' commitment levels to genuinely improving and supporting community hubs are significant, and their overall goals align, which include making the community services and management of services stronger and more accessible (Queen's 
Printer for Ontario, 2015). Notably, delivery models that currently exist and effectively meet specific community needs are highlighted in the research process, which contribute to the foundation created to overcome these barriers.

Another key aspect of this research involved the development of a foundation that empowers communities. Pitre highlights that her team's work as an Advisory Group sparked a necessary conversation and relationship between communities and their local groups, municipalities and the Province (Queen's Printer for Ontario, 2015). Although Pitre and her team's report identifies barriers, obstacles and challenges, its underlying purpose is to explore opportunities. To support these opportunities, Ontario's Community Hubs Strategic Framework and Action Plan, 2015 presents thorough and grounded recommendations that focus on removing barriers that exist, encouraging integrated service delivery, generating solutions that address inclusive, long-term local planning, providing sustainable financial support for community hubs so that local capacity can be optimized, developing incentives to support these actions, and following through by monitoring actions and associated outcomes, as well as evaluating those outcomes (Queen's Printer for Ontario, 2015).

Additional challenges that community hubs have encountered are organized under three general categories (Table 4): 1) planning, 2) integrated service delivery and 3) community infrastructure/public properties (Queen's Printer for Ontario, 2015). However, these challenges can be viewed as opportunities to improve and strengthen the existing framework, and provide an even more effective opportunity to strengthen the existing system's resilience. The main challenge, or in the context of this paper, the main opportunity, is recognizing what exists, and then addressing the potential to expand and improve the existing framework and systems. A key discovery through Karen and her team's research is that community hubs across the Province are successfully overcoming barriers because of strong leadership and a focus on effective collaboration (Queen's Printer for Ontario, 2015). This theme has been apparent throughout this paper, highlighting the importance of an all-encompassing, placebased approach with a specific focus on public participation and collaboration. 
Table 4- Issues That Present Opportunities for Ontario's Community Hubs Strategic Framework and Action Plan, 2015 to Address Resilience at a Neighbourhood-scale (Opportunities to address resilience at a neighbourhood-scale, or that align with a resilience approach are in bold italics)

\begin{tabular}{|c|c|}
\hline ISSUE & DESCRIPTION \\
\hline $\begin{array}{l}\text { 1) Planning } \\
\text { - Aim is to bring all of the ministries together } \\
\text { - Each reference to the community hub strategy } \\
\text { is slightly different depending on the ministry } \\
\text { - Requires changes in behaviour, policy, and } \\
\text { legislation + time and strong leadership } \\
\text { * Local communities know best what is needed } \\
\text { for their community } \\
\text { Currently, the Province is undertaking multiple } \\
\text { planning reviews, and it will be important to } \\
\text { ensure the provincial interest and local } \\
\text { mandate is reflected. } \\
\text { There is an opportunity in the context of these } \\
\text { reviews to require more integrated local } \\
\text { planning }\end{array}$ & $\begin{array}{l}\text { There are two major challenges to co- } \\
\text { ordinated planning: } \\
\text { - Need for a provincial community } \\
\text { planning table } \\
\text { - Need for Multiple local planning tables } \\
\text { - Current ministry planning is done } \\
\text { vertically, not horizontally } \\
\text { - There is currently no single place in } \\
\text { government to bring together all } \\
\text { community planning } \\
\text { - Leaders of community hubs have to deal } \\
\text { with multiple contact points, and } \\
\text { unorganized, incompatible policies and } \\
\text { processes (have to deal with multiple } \\
\text { ministries and multiple ministry programs } \\
\text { for varying services) } \\
\text { - Leadership and accountability is an } \\
\text { issue } \\
\text { - No designated lead for overall } \\
\text { community planning; it currently includes } \\
\text { municipalities, school boards, social } \\
\text { services, health and long-term care } \\
\text { agencies, as well as many others } \\
\text { - Difficult to clarify roles (involve } \\
\text { multiple local partners as well as } \\
\text { provincial interests) } \\
\text { - Local planning is further complicated by } \\
\text { geographical boundaries and agencies that } \\
\text { do not align } \\
\text { Some of the local planning challenges that } \\
\text { have also been identified include: } \\
\text { - Lengthy and costly process to assess the } \\
\text { needs of the community, identify the } \\
\text { services and service providers to meet } \\
\text { these needs and develop and maintain the } \\
\text { partnerships }\end{array}$ \\
\hline
\end{tabular}




\begin{tabular}{|c|c|}
\hline & $\begin{array}{l}\text { - Zoning by-laws and differing regulatory } \\
\text { regimes conflicting with the establishment } \\
\text { of community hubs } \\
\text { - Government funding approval processes } \\
\text { that are not aligned and with different } \\
\text { eligibility criteria } \\
\text { - School boards with a mandate and a } \\
\text { process to look at the education } \\
\text { requirements in a community. In the } \\
\text { absence of a community lead, they often } \\
\text { have the burden to take into consideration } \\
\text { the full value of schools as community } \\
\text { assets } \\
\text { - No framework to determine the viability } \\
\text { of public ownership of surplus property- } \\
\text { either for a portion of the site or the entire } \\
\text { site } \\
\text { - No inventory of surplus public } \\
\text { properties available to local planners and } \\
\text { community groups }\end{array}$ \\
\hline $\begin{array}{l}\text { 2) Integrated Service Delivery } \\
\text { The importance of going beyond co-location } \\
\text { towards truly integrated service delivery } \\
\text { The Province funds several programs and } \\
\text { services that could be leveraged or integrated }\end{array}$ & $\begin{array}{l}\text { A number of barriers impede the progress } \\
\text { towards an integrated service delivery } \\
\text { model-these barriers include: } \\
\text { - Start-up Funding } \\
\text { - Funding Silos } \\
\text { - Transfer Payments and Accountability } \\
\text { - Measuring Inputs, not Outcomes } \\
\text { - Sustainable Funding } \\
\text { - Privacy Legislation } \\
\text { - Local Capacity and Resources } \\
\text { * Government should move away from a } \\
\text { one-size fits all approach to service } \\
\text { provision and should instead look at } \\
\text { streaming clients according to the level } \\
\text { and nature of support they require } \\
\text { *While funding in silos can be a problem } \\
\text { in terms of community hub development, } \\
\text { ongoing funding is also a challenge in } \\
\text { terms of sustainability. }\end{array}$ \\
\hline
\end{tabular}




\begin{tabular}{|c|c|}
\hline & $\begin{array}{l}\text { Many groups have stated that the long- } \\
\text { term viability and flexibility of a } \\
\text { community hub depends on its ability to } \\
\text { adapt and respond to evolving community } \\
\text { needs } \\
\text {-To help cover some of their capital and } \\
\text { operating costs, Community hubs are often } \\
\text { discouraged from including commercial } \\
\text { operations } \rightarrow \text { Consideration should be } \\
\text { given to allowing for commercial space } \\
\text { that is compatible with the community hub } \\
\text { and serves the local community, and } \\
\text { supports the sustainability of the } \\
\text { community hubs business model. }\end{array}$ \\
\hline $\begin{array}{l}\text { 3) Community Infrastructure/Public } \\
\text { Property } \\
\text { Example: one organization wanted to buy a } \\
\text { school to leverage affordable housing funding, } \\
\text { but could not get the financing to pay market } \\
\text { value for the school. The need for affordable } \\
\text { housing in the community was evident, but } \\
\text { there was no way for the property to be } \\
\text { "priced" in a way that recognized the broader } \\
\text { social value of affordable housing to the } \\
\text { community. } \\
>\text { This planning and broader consideration of } \\
\text { socio-economic value is a challenge that } \\
\text { should not be borne by the Ministry of } \\
\text { Education and school boards alone. } \\
\text { Although many groups talked about repurposing } \\
\text { existing public properties, it was also heard that } \\
\text { assets for the future need to be better designed } \\
\text { to respond to the changing needs and } \\
\text { demographics of local communities. }\end{array}$ & $\begin{array}{l}\text { In some cases there is excess, } \\
\text { underutilized space, and in other cases, } \\
\text { there is a lack of space. } \\
\text { Key barriers related to retaining and using } \\
\text { public properties for community hubs: } \\
\text { - No accessible, comprehensive Public } \\
\text { Properties Database } \\
\text { - Planning in Silos } \\
\text { - Sale at Fair Market Value (FMV) } \\
\text { Circulation Process for Surplus } \\
\text { - } \quad \text { Property } \\
\text { - Capital Funding for Community Hubs } \\
\text { Property Management, Liability and } \\
\text { Security Issues } \\
\text { Design of New Buildings } \\
\text { - Currently the Province maintains a } \\
\text { database at Infrastructure Ontario for } \\
\text { surplus property, but it does not include a } \\
\text { comprehensive inventory that can be } \\
\text { accessed by all } \\
\text { - There is no capital planning that looks at } \\
\text { co-location of compatible uses, which } \\
\text { could lead to integrated service delivery } \\
\text { in a community hub }\end{array}$ \\
\hline
\end{tabular}




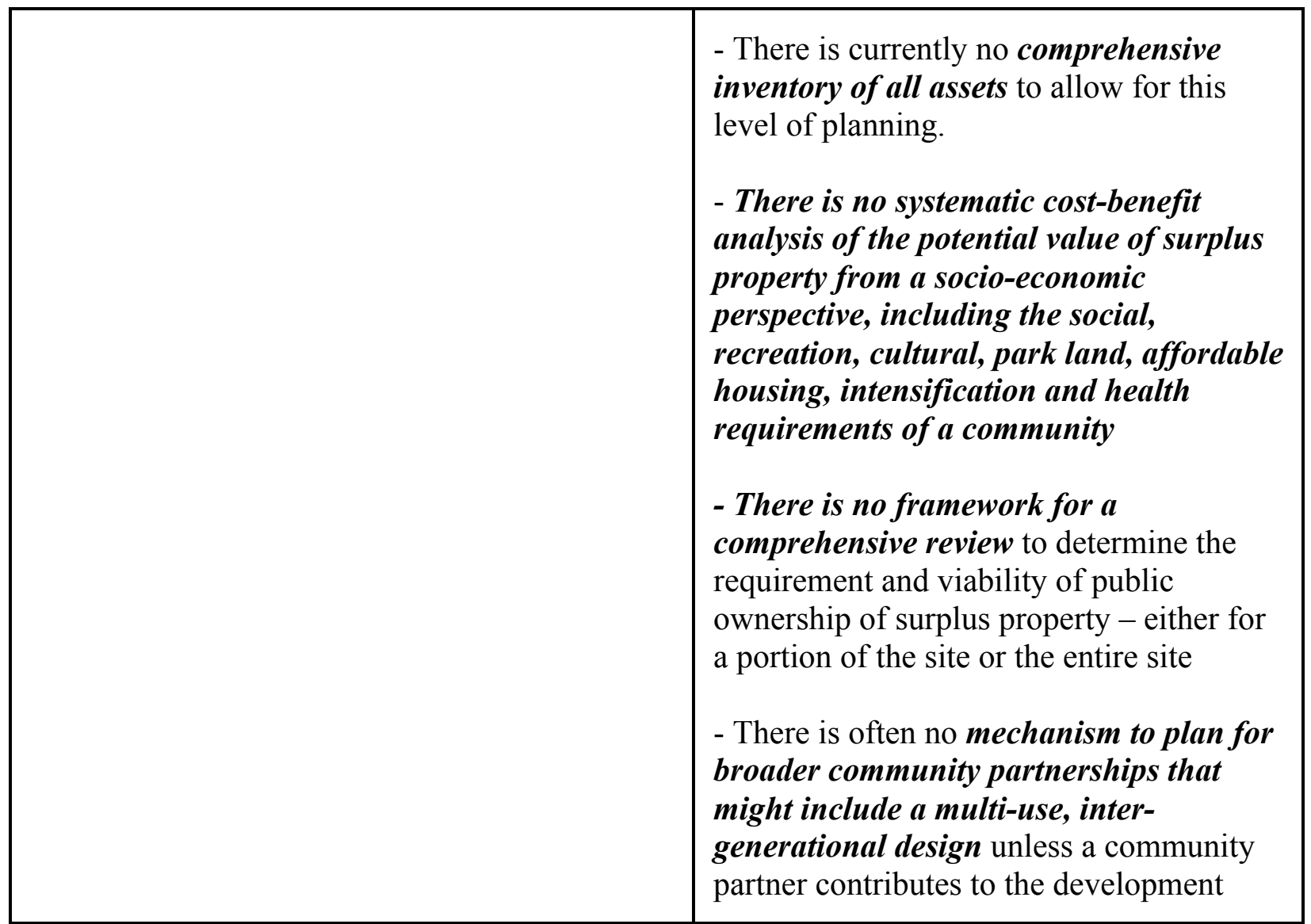

Information sourced from Ontario's Community Hubs Strategic Framework and Action Plan, 2015 (Queen's Printer for Ontario, 2015).

Although these issues exist, it is clear that there are many opportunities to address these challenges with a resilience approach. The major theme that can be acknowledged here is that local level planning and solutions more effectively serve the needs of neighbourhoods and associated communities, and there is a strong desire to implement them. Throughout this paper, and highlighted in the above table, the argument is made that local communities and neighbourhood residents know their neighbourhoods best, and thus, know what their communities need more than any other groups and organizations. Fortunately, in addition to high-quality responses from both government and non-government groups found in Ontario's Community Hubs Strategic Framework \& Action Plan, 2015, the various involved groups' commitment levels to genuinely improve and support community hubs is significant (Queen's Printer for Ontario, 2015). Notably, it is also clear from this analysis that many groups believe that in order for community hubs to maintain flexibility and feasibility they must be adaptable and effectively respond to the changing and growing needs of the community. This is a 
positive resilience approach, however, from the author's empirical research, it can also require the reallocation of resources (such as staffing or programming). Unfortunately, this reallocation of services or resources can cause disturbance or deprivation in other systems, weakening the resilience of the system overall, and thus having more of a negative or selfish connotation. In this regard, and to reinforce a major finding in chapter 5 of this paper, neighbourhood resilience approaches must not only ensure that specific systems are resilient, but also that the system is resilient as a whole.

Focusing on the priority of strengthening communities, there is a clear foundation and desire in this framework to enhance the existing model and apply a resilience lens. With the need for resilience established, a current policy that wishes to strengthen its communities, and the ability to address resilience, the next question that arises is how can Ontario's Community Hubs Strategic Framework \& Action Plan, 2015 adequately address resilience at the neighbourhood-scale? It is important to understand how to incorporate resilience into Ontario's Community Hub Strategic Framework and Action Plan because the appropriate strategies for this are not defined. Resilience in a community hub context is an important element of truly sustainable development, and integrating resilience within this existing framework is the next logical step for Ontario. 


\subsection{RECOMMENDATIONS- A NEIGHBOURHOOD RESILIENCE FRAMEWORK \& "RESILIENCE TOOLKIT"}

It has been made clear thus far, through a literature review and case study analysis, that a resilience lens must be applied at all scales simultaneously in order to have real impact, and the neighbourhood-scale is one that has not been explored to an extensive degree. Thus, there is little work done in regards to developing a resilience standard or thorough framework at this scale, other than some resilience work highlighted by Gerdes (2014) in the Bayview area in San Francisco, and some investigations into existing neighbourhoods and their capacity to support climate change adaptations (Williams et al., 2012). Other organizations such as Bay Localize (2015) and the Fraser Basin Council et al. (2015) have addressed the need for neighbourhood resilience, provided guidelines and tools to evaluate and build neighbourhood resilience, but a formal framework and plan does not exist in Ontario.

It is apparent that comprehensive resilience strategies at the neighbourhood-scale must be explored further within a framework, which addresses not only the immediacy of climate change, and fluctuating social and economic environments, but also the need for civic engagement in order to ensure its success. The neighbourhood-scale supports public interaction and collaboration, and thus creates a strong community relationship within the neighbourhood, which has been highlighted as a key resilience characteristic in this paper. This theme is also apparent in the community hubs framework, which creates an opportunity to address resilience at the local level through an existing framework. Neighbourhood resilience strategies are specific to the neighbourhood, allowing for the approaches to stay clear of 'cookie-cutter' solutions that may not be the most effective for that neighbourhood, which again underlines a main goal for community hubs and service provision. The other benefit of this scale is that positive actions can occur in a more timely manner, as it does not have the same implications and timelines as strategies that are citywide, and involve multiple levels of governments' approval and processes.

Table 5 outlines a more holistic framework and recommendation suggested by the Fraser Basin et al. (2015), as well as a "Resilience Toolkit" established by Bay Localize (2015) that together, and in addition to Uda (2016)'s framework provided in the case study chapter 5.0, 
provide insight as to how Ontario's Community Hub Strategic Framework and Action Plan, 2015 can incorporate resilience into its existing model. These recommendations are meant to introduce the concept of applying a resilience lens to an appropriate existing system.

Table 5 - Suggested Framework and "Resilience Toolkit"

\begin{tabular}{|c|c|c|}
\hline STRATEGY & DESCRIPTION & $\begin{array}{l}\text { MAIN FINDINGS, } \\
\text { OPPORTUNITIES } \\
\text { \& RECOMMENDATIONS }\end{array}$ \\
\hline $\begin{array}{l}\text { Building Resilient } \\
\text { Neighbourhoods } \\
\text { Project } \\
\text { Source: Fraser Basin } \\
\text { Council et al. (2015) } \\
\text { Aim: focus on long- } \\
\text { term adaptive capacity } \\
\text { that is inclusive and } \\
\text { all-encompassing }\end{array}$ & $\begin{array}{l}\text { Description } \\
\text { - high-level, all- } \\
\text { encompassing, holistic } \\
\text { neighbourhood } \\
\text { resilience framework } \\
\text { and approach } \\
\text { - based on the idea that } \\
\text { communities are } \\
\text { complex systems } \\
\text { - implements more than } \\
\text { just sector-specific } \\
\text { strategies that tend to } \\
\text { leave people out } \\
\text { Examples have a focus } \\
\text { on: } \\
\text { i) positive attitudes and } \\
\text { values } \\
\text { ii) proactive and } \\
\text { ongoing leadership } \\
\text { development and } \\
\text { planning } \\
\text { iii) a localized economy } \\
\text { iv) a high degree of } \\
\text { local access to and } \\
\text { collective ownership of } \\
\text { resources and assets } \\
\text { - accessible green space } \\
\text { and ecosystem } \\
\text { education and } \\
\text { conservation } \\
\text { - accessible public } \\
\text { gathering spaces and }\end{array}$ & $\begin{array}{l}\text { - understand neighbourhood issues and } \\
\text { develop strong connections between } \\
\text { them and the existing or planned } \\
\text { neighbourhood systems } \\
\text { - encourage participation at all levels } \\
\text { - consider all citizen interests, and } \\
\text { engage all citizens (especially for } \\
\text { solutions involving local institutions and } \\
\text { social capital) } \\
\text { - encourage socially diverse } \\
\text { cohesiveness (helps meet challenges } \\
\text { now and in the future) } \\
\text { - generate and sustain proactive } \\
\text { responses and actions } \\
\text { - understand the diverse but interacting } \\
\text { systems in a neighbourhood } \\
\text { - promote leadership from multiple } \\
\text { sectors } \\
\text { - identify priorities (determined by } \\
\text { degree of impact) e.g. community- } \\
\text { controlled finance, land and buildings, } \\
\text { and the significance of decision- making } \\
\text { at the local level } \\
\text { How? } \\
\text { Involve local governments, community } \\
\text { organizations, and } \\
\text { neighbours/community members that } \\
\text { have specific roles: } \\
\text { Local Government Examples } \\
\text { - grants and incentives } \\
\text { - community engagement } \\
\text { - programming (educational, recreational } \\
\text { and cultural) }\end{array}$ \\
\hline
\end{tabular}




\begin{tabular}{|c|c|c|}
\hline & $\begin{array}{l}\text { shops } \\
\text { - resilience-based land } \\
\text { use plans } \\
\text { - public policies that } \\
\text { support specific local } \\
\text { needs (housing and food } \\
\text { security) } \\
\text {-street-level activities } \\
\text { (connects neighbours) } \\
\text {-infrastructure that } \\
\text { promotes sharing } \\
\text { (gardening tools, } \\
\text { supplies, bikes, } \\
\text { knowledge) } \\
\text {-neighbourhood } \\
\text { renewable energy } \\
\text { supplies } \\
\text { - local exchange and } \\
\text { trading hubs }\end{array}$ & $\begin{array}{l}\text { - long-term resilience planning } \\
\text { - financial support development } \\
\text { - zoning, by-laws and policies } \\
\text { - Community Economic Development } \\
\text { Planning } \\
\text { - communicate and enhance best } \\
\text { practices } \\
\text { Community Organizations } \\
\text { - community building and establishing } \\
\text { connections } \\
\text { - neighbourhood communications } \\
\text { - provide inclusive services, including } \\
\text { vulnerable and marginalized populations } \\
\text { - community engagement } \\
\text { - asset mapping } \\
\text { - ensuring neighbourhood accessibility } \\
\text { and beautification } \\
\text { - Business Improvement Areas } \\
\text { - keep inventory of local skills } \\
\text { - community financing programs } \\
\text { - local business mapping } \\
\text { Neighbours/Community Members } \\
\text { - implement and enhance street-level } \\
\text { activities that are accessible to all } \\
\text { - share skills, expertise and knowledge } \\
\text { - establish collective goals and } \\
\text { ownership } \\
\text { - participate in community activities } \\
\text { (gardening, compost, building) } \\
\text { - local/community investment funds } \\
\text { - household asset maps and sharing }\end{array}$ \\
\hline $\begin{array}{l}\text { Resilience Toolkit } \\
\text { Source: Bay Localize } \\
\text { (2015) } \\
\text { Aim: build and } \\
\text { support resilient } \\
\text { communities by } \\
\text { providing for } \\
\text { everyone's needs in an } \\
\text { equitable and } \\
\text { sustainable way }\end{array}$ & $\begin{array}{l}\text { Description } \\
\text { - a project of Earth } \\
\text { Island Institute, a non- } \\
\text { profit, public interest, } \\
\text { membership } \\
\text { organization } \\
\text { - improves regional } \\
\text { capacity } \\
\text { - provides local leaders } \\
\text { with flexible tools, } \\
\text { models, and policies }\end{array}$ & $\begin{array}{l}\text { i) Climate Risk and Job Opportunity } \\
\text { Assessment } \\
\text { - opportunities such as jobs and business } \\
\text { ventures can stem from climate and } \\
\text { energy risks } \\
\text { - background knowledge of the } \\
\text { neighbourhood is helpful in determining } \\
\text { what is viable at a local level }\end{array}$ \\
\hline
\end{tabular}




\begin{tabular}{|c|c|c|}
\hline $\begin{array}{l}\text { See Appendices 1A- } \\
1 D \text { for full summaries }\end{array}$ & 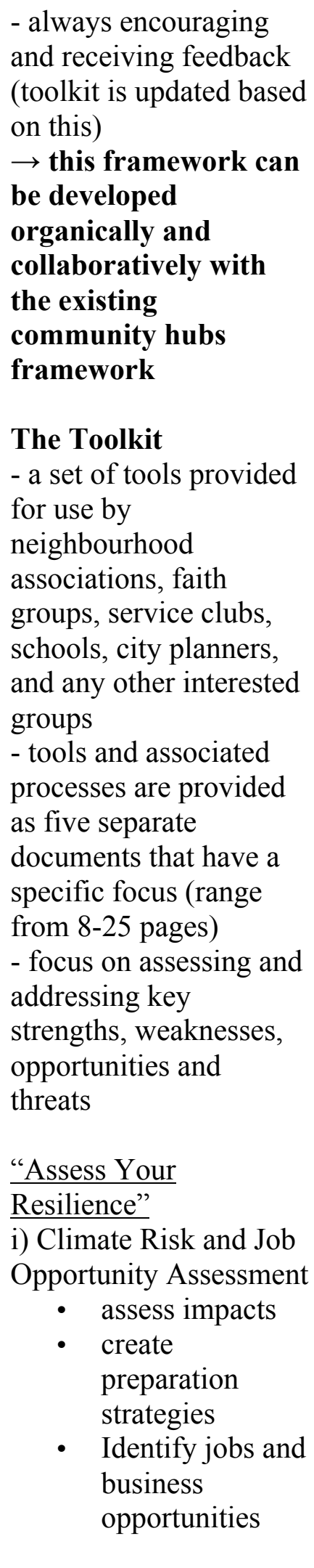 & $\begin{array}{l}\text { ii) Local Resilience Assessment } \\
\text { - provides a platform to assess local } \\
\text { systems and their capacity to address } \\
\text { resilience } \\
\text { - helpful in identifying areas of } \\
\text { importance and main priorities } \\
\text { - sub-groups focus on specific systems } \\
\text { (e.g. food, water, energy) and assess the } \\
\text { resilience of that system } \\
\text { - incorporation of human rights ensures } \\
\text { an equitable approach } \\
\text { - this assessment creates local ownership } \\
\text { and promotes high-quality and diverse } \\
\text { systems } \\
\text { - sparks a discussion between local } \\
\text { groups in order to address decisions, } \\
\text { processes, findings, questions, goals and } \\
\text { next steps } \\
\text { iii) Roots of Equity and Resilience } \\
\text { - users are inspired by existing examples } \\
\text { of local resilience } \\
\text { - creates connections between the } \\
\text { community and local social justice } \\
\text { movements and leaders } \\
\text { - history provides useful information to } \\
\text { develop resilience in a neighbourhood } \\
\text { - generates knowledge and facilitates } \\
\text { discussions amoung groups that might } \\
\text { not normally communicate (create } \\
\text { connections) } \\
\text { - addresses the gaps in the knowledge } \\
\text { base } \\
\text { iv) Creating Your Plan for Change } \\
\text { - helps to build and maintain consensus } \\
\text { amoung local groups in regards to } \\
\text { strategic goals } \\
\text { - provides a platform to break down the } \\
\text { - the tool is easy to use, provides simple } \\
\text { research and then share with the rest of }\end{array}$ \\
\hline
\end{tabular}




\begin{tabular}{|c|c|}
\hline 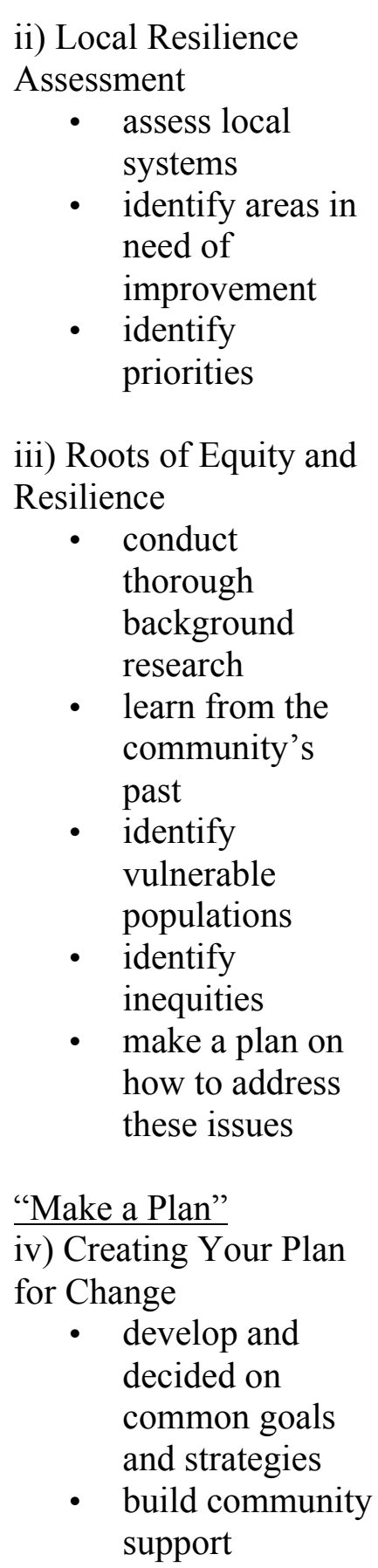 & $\begin{array}{l}\text { the group } \\
\text { - all members in the sub-groups should } \\
\text { be equally dedicated and informed, and } \\
\text { have the same goals in mind (cohesion } \\
\text { and a clear/common understanding of } \\
\text { the overall goal is necessary) } \\
\text { - this document includes a ten step } \\
\text { process that is not meant to be finished } \\
\text { quickly (takes about two hours to } \\
\text { complete one to two steps) covering } \\
\text { everything from background research, } \\
\text { outreach, and establishing a vision, to } \\
\text { setting goals, identifying assets and } \\
\text { developing strategies } \\
\text { - encourages the creation of a plan to } \\
\text { measure impacts and to consider next } \\
\text { steps }\end{array}$ \\
\hline
\end{tabular}

The main observation that can be made after an analysis of these models and recommendations, in addition to Uda (2016)'s framework that focuses primarily on physical aspects and resilience strategies, is that a one-size-fits-all model does not and cannot exist. Neighbourhoods and the communities within them are diverse, constantly changing and require specific, customized strategies that are flexible, equitable and sustainable in nature. 
The analyses, observations and recommendations expressed in this paper are just the start of a much needed conversation in regards to resilience at the neighbourhood-scale, and requires support from all levels of government, the empowerment of local communities and leaders, and a comprehensive, proactive strategy that is influenced by, and shared with, all members of the community. 


\subsection{CONCLUSIONS AND FINAL RECOMMENDATIONS}

This research exposes the reality that neighbourhood resilience is not only needed, but the work necessary to implement it can start now. It is meant to start a dialogue about how a resilience lens can be applied at the neighbourhood-scale to existing systems and frameworks. Although citywide resilience strategies play a large role in regards to climate change and responding to its associated threats and shocks, as well as major societal changes, neighbourhood resilience can have an impact on meeting immediate, specific needs now and in the future, and requires further attention. It became clear that a new approach is required to make a real resilient foundation for a neighbourhood, as sustainability cannot solely achieve resilience.

The complications that arise from implementing resilience work at the neighbourhood-scale stem from the fact that it can be quite an elaborate task in regards to the procedures and strategies that are necessary to apply to individual components of a neighbourhood and a neighbourhood as a whole. There is a need to make these procedures and strategies more efficient before integrating them into Ontario's Community Hubs Strategic Framework and Action Plan, 2015. These strategies are found in the case studies analysis and main findings, the more holistic framework and recommendation suggested by Fraser Basin et al. (2015), the “Resilience Toolkit” established by Bay Localize (2015) and Uda (2016)'s framework. Through this investigation, it is clear that neighbourhood resilience requires a holistic, allencompassing and flexible approach, as neighbourhoods are complex and always changing.

Next steps required to further develop resilience research at this scale include support and leadership on the provincial, municipal and local government levels, including education and awareness. This also includes funding resilience, not just after disasters and shocks occur, but proactively and sustainably. The overall goal is to increase knowledge about and pressure for resilient neighbourhoods from all levels (public, private, local and provincial). Resilience is beginning to show up on planners' and related professionals' radar screens, as well as the province in regards to addressing neighbourhood resilience within the existing community hubs framework. However, there is not much current resilience research at the neighbourhood- 
scale because the pressure, public demand and regulations needed are not set in place with a strong framework and streamlined guidelines.

Moving forward, the overall approach to neighbourhood resilience work presented in this paper should be applied to existing community hubs within Ontario neighbourhoods, especially where recommendations have a good chance of being considered, and with a community of engaged people (evident in Ontario's Community Hubs Strategic Framework and Action Plan, 2015). As the approach and strategies develop, different neighbourhood types should be explored in regards to their social structure (rich and poor, high and low-risk, demographics, service and resource accessibility), and physical structure (i.e. location, built form, urban, rural, high-rise and low-rises, ecosystems and natural landscapes). Through these case studies, strengths and weaknesses, thus opportunities and constraints can be identified and the effectiveness of certain approaches, strategies and priorities can be assessed, shared and enhanced.

There are a few concerns that need to be addressed moving forward. Resilience strategies and approaches can lead to inequalities if resilience is associated with a price, meaning that the rich can afford to live in resilient neighbourhoods. On the same note, and in line with the reallocation of services and systems concept discussed in this paper, the wealthy or more powerful community members may end up securing resilience while the resilience of others suffers as a result. On a broader scale, resilience could become too central, where resilience strategies deplete sustainable strategies. This highlights the need for a neighbourhood to be resilient as a whole, as well as the specific systems within it. This also underlines the need to establish positive and sustainable common goals and values, which help to prevent inequalities from occurring.

Overall, implementing a resilience lens at the neighbourhood scale is not only a highly effective approach in regards to building and maintaining physical systems that meet essential needs in all conditions, but also an approach that fosters a sense of community, creates connections across varying professional fields, community groups and neighbours, and involves a process that can be enjoyed and influenced by all members of the community. 
Resilience at the neighbourhood-scale is a complex topic of discussion that is rapidly gaining support, and requires a multidimensional approach that can effectively change as much as the neighbourhood it supports.

"Nothing endures but change" - Heroclitus (544 BC) 


\section{REFERENCE LIST}

Australian Social Inclusion Board. (2009). Building Inclusive and Resilient Communities. Australian Government. Retrieved from:

http://www.emergencyvolunteering.com.au/docs/Building_Inclusive_and_Resilient_C ommunities.pdf

Bach, R., Doran, R., Gibb, L., Kaufman, D., \& Settle, K. (2010). Policy Challenges in Supporting Community Resilience. Working paper presented at the London Workshop of the Multinational Community Resilience Working Group.

Bahadur, A. V., Ibrahim, M., \& Tanner, T. (2013). Characterising resilience: unpacking the concept for tackling climate change and development. Climate and Development, 5(1), $55-65$.

Barton H., Grant, M., \& Guise, R. (2003). Shaping neighbourhoods: a guide for health, sustainability and vitality. London, UK: Spon Press.

Bay Localize. (2015). Building Resilience Toolkit. Retrieved from:

www.baylocalize.org/toolkit

Bocchini, P., Frangopol, D. M., Ummenhofer, T., \& Zinke, T. (2014). Resilience and Sustainability of Civil Infrastructure: Toward a Unified Approach. ASCE Journal of Infrastructure Systems, 20(2), 04014004-1 - 04014004-16.

Brand, F. S., \& Jax, K. (2007). Focusing on the Meaning(s) of Resilience: Resilience as a Descriptive Concept and a Boundary Object. Ecology and Society, 12(1), 23.

Brower, S. (1996). Good Neighbourhoods: A study of in-town \& suburban residential environments. Praeger. Westport, CT.

Canadian International Development Agency. (1997). CIDA's Policy on Meeting Basic Human Needs. Retrieved from: http://www.acdi-cida.gc.ca.

Canadian Institute of Planners. (2016). Healthy Communities. Retrieved from: http://www.cipicu.ca/Topics-in-Planning/Healthy-Communities\#

City of Toronto. City Planning Division. (2015). Official Plan, Office Consolidation. Retrieved from: http://www1.toronto.ca/wps/portal/contentonly?vgnextoid=03eda07443f36410VgnVC M10000071d60f89RCRD

Collier, F., Hambling, J., Kernaghan, S., Kovacevic, B., Miller, R., Pérez, A. P., Richardson, E., \& Macmillan, S. (2014). Tomorrow's cities: a framework to assess urban resilience. Proceedings of the ICE - Urban Design and Planning, 167(2), 79-91. 
Colten, C. (2010). Building Community Resilience: A Summary of Case Studies from Charleston, Gulfport, and Memphis. CARRI Research Report 9. Louisiana State University.

Coulton, C. (2012). Defining Neighbourhoods for Research and Policy. Cityscape, 14(2), 231236.

Davoudi, S. (2012). Resilience: A Bridging Concept or a Dead End? Planning Theory \& Practice, 13(2), 299-307.

Fraser Basin Council, Community Social Planning Council, Transition Victoria, \& CCCR. (2015). Strengthening Neighbourhood Resilience- Opportunities for Communities \& Local Government. Retrieved from:

http://www.fraserbasin.bc.ca/_Library/SPC_Documents/Resilient_Neighbourhoods_w eb.pdf

Fünfgeld, H. \& McEvoy, D. (2012). Resilience as a Useful Concept for Climate Change Adaptation? Planning Theory \& Practice, 13:2, 299-307.

Gerdes, J. (2014, May 7). San Francisco neighbourhood models resilience planning from the grassroots up. Citiscope Global News. Retrieved from http://www.citiscope.org/story/2014/san- francisco-neighbourhood-models-resilienceplanning-grassroots\#sthash.rmhj6UH6.dpuf

Godschalk, D. R. (2003). Urban Hazard Mitigation: Creating Resilient Cities. ASCE Natural Hazards Review, 4(3), 136-143.

Henderson, K. (2010). Briefing: Adapting to Climate Change. Proceedings of the Institute of Civil Engineers: Urban Design and Planning, 163(2), 53-58.

ICLEI. (2015). Resilient Cities Report 2015. Retrieved from: http://resilientcities.iclei.org/fileadmin/sites/resilientcities/files/Resilient_Cities_2015/RC2015_Congress_Report_Final.pdf

Jenks, M., \& Dempsey, N. (2007). Defining the neighbourhood: Challenges for empirical research. The Town Planning Review, 78(2), 153-168, 170-177.

Kearns, A. \& Parkinson, M. (2001). The significance of neighbourhood. Urban Studies, Vol. 38, No. 12, 2103-2110. Retrieved from: http://usj.sagepub.com/content/38/12/2103.extract\#cited-byca

MacQueen, M., McLellan, E., Metzger, D., Kegeles, S., Strauss, R., Scotti, R., Blanchard, L., \& Trotter, R, II. (2001). What Is Community? An Evidence-Based Definition for Participatory Public Health. American Journal of Public Health: December 2001, Vol. 91, No. 12, pp. 1929-1938. 
Martin, D. G. (2003). Enacting Neighbourhood. Urban Geography, 24(5), 361-385.

Maslow, A. (1943). A Theory of Human Motivation. Psychological Review, 50(4), 370-390.

Park, J., Seager, T. P., \& Rao, P. S. C. (2011). Lessons in Risk- Versus Resilience-Based Design and Management. Integrated Environmental Assessment and Management, 7(3), 396-399.

Norris, F. H., Stevens, S. P., Pfefferbaum, B., Wyche, K. F., \& Pfefferbaum, R. L. (2008). Community Resilience as a Metaphor, Theory, Set of Capacities, and Strategy for Disaster Readiness. American Journal of Community Psychology, 41, 127-150.

Park, J., Seager, T. P., Rao, P. S. C., Convertino, M., \& Linkov, I. (2013). Integrating Risk and Resilience Approaches to Catastrophe Management in Engineering Systems. Risk Analysis, 33(3), 356-367.

Province of Ontario. Ministry of Municipal Affairs and Housing. (2006). Growth Plan for the Greater Golden Horseshoe. Retrieved from:

https://www.placestogrow.ca/index.php?option=com_content\&task=view\&id=9\&Item $\mathrm{id}=14$

Province of Ontario. Ministry of Municipal Affairs and Housing. (2014). Provincial Policy Statement. Retrieved from: http://www.mah.gov.on.ca/Page10679.aspx

Queen's Printer for Ontario. (2015). Community Hubs in Ontario: A Strategic Framework \& Action Plan. Retrieved from: https://www.ontario.ca/page/community-hubs

Quirk, V. (2013). “AIA Puts Resiliency on the Agenda: Resilience Is the New Green.” Retrieved from: http://www.archdaily.com/432802/aia-puts-resiliency-on-the-agendaresilience-is-the-new-green/

Taylor, R. (2012). Defining Neighbourhoods in Space and Time. Cityscape, 14(2), 225-230.

Uda, M. (2016). Sustainable and Resilient Neighbourhood Design. University of Toronto.

Walker, B., \& Salt, D. (2012). Resilience practice: building capacity to absorb disturbance and maintain function - How can landscapes and communities adapt and transform in a changing world? Washington DC: Island Press.

Wilding, N. (2011). Exploring community resilience in times of rapid change. Published by Fiery Spirits Community of Practice. Retrieved from: http://fieryspirits.com/page/exploring-resilience

Williams, K., Joynt, J. L. R., Payne, C., Hopkins, D., \& Smith, I. (2012). The conditions for, and challenges of, adapting England's suburbs for climate change. Building and Environment, 55, 131-140. 